\title{
Direct and indirect effects of cytomegalovirus-induced $\gamma \delta$ T cells after kidney transplantation
}

\section{Lionel Couzi ${ }^{1,2,3}$, Vincent Pitard ${ }^{1,2}$, Jean-François Moreau ${ }^{1,2,4}$, Pierre Merville ${ }^{1,2,3}$ and Julie Déchanet-Merville ${ }^{1,2}$}

1 Université de Bordeaux, Bordeaux, France

2 UMR 5164, Centre National de la Recherche Scientifique, Bordeaux, France

${ }^{3}$ Service de Néphrologie, Transplantation, Dialyse, Centre Hospitalier Universitaire de Bordeaux, Bordeaux, France

${ }^{4}$ Centre Hospitalier Universitaire de Bordeaux, Laboratoire d'immunologie, Bordeaux, France

\section{Edited by:}

Dieter Kabelitz, Christian-Albrechts

University Kiel, Germany

Reviewed by:

Koji Yasutomo, University of

Tokushima, Japan

David Vermijlen, Université Libre de

Bruxelles, Belgium

*Correspondence:

Lionel Couzi, CHU de Bordeaux, Hôpital Pellegrin,

Néphrologie-Transplantation-Dialyse, place Amélie Raba Léon, Bordeaux 33076, France

e-mail: lionel.couzi@chu-bordeaux.fr
Despite effective anti-viral therapies, cytomegalovirus (CMV) is still associated with direct (CMV disease) and indirect effects (rejection and poor graft survival) in kidney transplant recipients. Recently, an unconventional T cell population (collectively designated as $V \delta 2^{\text {neg }} \gamma \delta T$ cells) has been characterized during the anti-CMV immune response in all solid-organ and bone-marrow transplant recipients, neonates, and healthy people. These CMV-induced $V \delta 2^{\text {neg }} \gamma \delta T$ cells undergo a dramatic and stable expansion after CMV infection, in a conventional "adaptive" manner. Similarly, as CMV-specific CD8 $+\alpha \beta T$ cells, they exhibit an effector/memory TEMRA phenotype and cytotoxic effector functions. Activation of $V \delta 2^{\text {neg }} \gamma \delta T$ cells by CMV-infected cells involves the $\gamma \delta T$ cell receptor (TCR) and still ill-defined co-stimulatory molecules such as LFA-1. A multiple of $V \delta 2^{\text {neg }} \gamma \delta$ TCR ligands are apparently recognized on CMV-infected cells, the first one identified being the major histocompatibility complex-related molecule endothelial protein $C$ receptor. A singularity of CMV-induced $\mathrm{V} \delta 2^{\text {neg }} \gamma \delta \mathrm{T}$ cells is to acquire CD16 expression and to exert an antibody-dependent cell-mediated inhibition on CMV replication, which is controlled by a specific cytokine microenvironment. Beyond the well-demonstrated direct anti-CMV effect of $V \delta 2^{\text {neg }} \gamma \delta T$ cells, unexpected indirect effects of these cells have been also observed in the context of kidney transplantation. CMV-induced $V \delta 2^{\text {neg }} \gamma \delta T$ cells have been involved in surveillance of malignancy subsequent to long-term immunosuppression. Moreover, CMV-induced CD16 $+\gamma \delta T$ cells are cell effectors of antibody-mediated rejection of kidney transplants, and represent a new physiopathological contribution to the well-known association between CMV infection and poor graft survival. All these basic and clinical studies paved the road to the development of a future $\gamma \delta$ T cell-based immunotherapy. In the meantime, $\gamma \delta T$ cell monitoring should prove a valuable immunological biomarker in the management of CMV infection.

Keywords: antibody-mediated rejection, cancer, cytomegalovirus, gamma-delta $T$ cells, lymphocytes, renal transplantation

\section{INTRODUCTION}

Kidney transplantation is the treatment of choice for patients with end-stage renal failure $(1,2)$. However, transplantation implies long-term chronic immunosuppression to avoid acute rejection and to extend graft survival. Chronic immunosuppression reshapes host-pathogen relationships, by modifying the type or changing the magnitude of immune responses against pathogens and tumor cells. Therefore, the two main complications associated with immunosuppressive therapies are opportunistic infections and cancer.

Cytomegalovirus infection is the most frequent opportunistic infection occurring after kidney transplantation. Human cytomegalovirus (CMV) is an ubiquitous human herpesviridae, with a double-stranded linear DNA genome of $235 \mathrm{~kb}$ (3). Primary CMV infection in an immunocompetent host is usually asymptomatic due to the establishment of a robust and specific adaptive immune response involving CMV-specific CD4+ T cells, CD8+ $\mathrm{T}$ cells, and IgG, which persist lifelong. Moreover, after primoinfection, all these actors contribute to inhibit virus reactivation (3). Despite effective anti-viral therapies, CMV is still associated with CMV infection or disease in immunocompromised kidney transplant recipients $(4,5)$. CMV infection is characterized by CMV DNAemia (CMV DNA in blood or plasma, also called CMV viremia) regardless of symptoms and occurs in about $50 \%$ of $\mathrm{CMV}$-seropositive patients $(\mathrm{R}+$, patients with peripheral blood CMV IgG) (6-10), and up to 70\% of donor-positive, seronegativerecipients $(\mathrm{D}+\mathrm{R}-)$ in the absence of anti-viral prophylaxis (1118). CMV disease can be a viral syndrome (CMV DNAemia with fever, malaise, leukopenia, and/or thrombocytopenia) or a tissueinvasive disease (where CMV is detected in the injured organs, mostly lungs, liver and intestines) $(4,5)$. It occurs in $15-20 \%$ of $\mathrm{D}+\mathrm{R}-$ patients and $5-10 \%$ of $\mathrm{R}+$ patients, with or without 
prophylaxis. Infections with high viral load require prolonged anti-viral therapy, which can lead to the emergence of CMV gene mutations associated with anti-viral resistance (mutations in UL97 or UL54 genes), a situation associated with high morbidity, graft loss, and death $(12,19-21)$. Moreover, CMV is also associated with indirect effects after kidney transplantation (22): worse patient and graft survivals (specially late-onset CMV infection or disease) (16, 23-28), more interstitial fibrosis/tubular atrophy (17), more acute rejection $(17,24,29-31)$, more other opportunistic infections (32-35), an increased cardiovascular risk (36), more newonset diabetes after transplantation $(37,38)$, and more graft artery stenosis $(39,40)$. Prophylactic anti-CMV immunoglobulin also prevents the development of early post-transplant non-Hodgkin lymphoma in kidney transplant recipients (41).

Cytomegalovirus-specific CD4+ and/or CD8+ T cell responses have been extensively documented after kidney transplantation (42-48). The efficacy of cell therapy protocols using expanded CMV-specific CD8 $+\mathrm{T}$ cells has demonstrated the central role played by these cells in the control of the virus (49). Therefore, it has been proposed to monitor these cells before and after transplantation to better use anti-CMV prophylaxis and therapy (50).

In 1999, we observed a massive expansion of a $\gamma \delta$ T cell population after CMV infection in kidney transplant recipients $(51,52)$. This CMV-induced $\gamma \delta \mathrm{T}$ cell expansion did not involve the V $\delta 2$ subset, which is usually the main subset of $\gamma \delta$ T cells observed in the peripheral blood. Surprisingly, this increase can concern any of the $\mathrm{V} \delta 1, \mathrm{~V} \delta 3$, and $\mathrm{V} \delta 5$ sub-populations (collectively designated as $\mathrm{V} \delta 2^{\text {neg }} \gamma \delta \mathrm{T}$ cells) (52). This initial observation, since largely confirmed by others, suggested that a population of $V \delta 2^{\text {neg }} \gamma \delta$ $\mathrm{T}$ cells might play an important role in the immune response to CMV infection, but raised many questions about these cells. At the afferent phase of the CMV immune response, where is their site of priming? When and how are naïve $\mathrm{V} \delta 2^{\text {neg }} \gamma \delta \mathrm{T}$ cells activated? At the efferent phase, where is their site of action? What is their function? When and how do they recognize target cells? This review summarizes the recent findings tentatively addressing these points and leading to the conclusion that $\mathrm{V} \delta 2^{\text {neg }} \gamma \delta \mathrm{T}$ cells are important actors of the anti-CMV immune response, with direct anti-CMV effects, but also unexpected indirect effects observed in the context of kidney transplantation.

\section{LOCALIZATION OF V $\delta 2^{\text {neg }} \gamma \delta$ T CELLS}

Once established, the expansion of circulating $\mathrm{V} \delta 2^{\text {neg }} \gamma \delta \mathrm{T}$ cells following CMV infection in kidney transplant recipients is prominent and stable over time (51-53). This subset, which represents $0.5 \%$ on average of the $\mathrm{T}$ cell pool in CMV-seronegative patients, reaches an average of $5-10 \%$ of the circulating $\mathrm{T}$ cell pool in CMV-seropositive patients, and up to $50 \%$ in some patients. This phenomenon is not exclusive to the kidney transplant scenario as $\mathrm{V} \delta 2^{\text {neg }} \gamma \delta \mathrm{T}$ cell peripheral blood expansion after CMV infection has been shown in other solid-organ transplantations (54-56), in recipients of hematopoietic stem cell transplantation (57-59), in immunodeficient children $(60,61)$, in neonates (62), in pregnant women (63), and in healthy individuals (64). CMV-specific CD4+ and CD8 $+\alpha \beta$ T cells on their own already represent around $5 \%$ of the $\mathrm{T}$ cell pool in CMV-seropositive healthy individuals (65) and accumulate in older people (66). V $\delta 2^{\text {neg }} \gamma \delta \mathrm{T}$ cell peripheral blood expansion further strengthens this high magnitude of the antiCMV immune response. This accumulation of CMV-induced $\mathrm{T}$ cells may exert a detrimental effect on host by reducing immunity against other pathogens and could contribute to the CMV-induced immune senescence (67).

One of the most intriguing questions regarding $V \delta 2^{\text {neg }} \gamma \delta \mathrm{T}$ cells is about their localization during the afferent and efferent phases of the immune response against CMV. To date, we still do not know where naïve $\mathrm{V} \delta 2^{\text {neg }} \gamma \delta \mathrm{T}$ cells are primed and where they exert their function. In physiological context, $V \delta 2^{\text {neg }} \gamma \delta \mathrm{T}$ cells are the first $\gamma \delta \mathrm{T}$ cell subset to emigrate from the thymus where they represent $1-15 \%$ of thymic $\mathrm{T}$ cells $(68-71)$. Although poorly represented in lymph nodes, they represent $15 \%$ of $\mathrm{T}$ cells in the spleen where they are located in the marginal zone and red pulp $(68,69,72)$. In tissues, $V \delta 2^{\text {neg }} \gamma \delta \mathrm{T}$ cells are occasional in the kidney and the lung $(68,69)$. However, up to $15 \%$ of liver $\mathrm{T}$ cells can be $\gamma \delta \mathrm{T}$ cells (73-75). They are predominantly found within normal human epithelia, with a selective accumulation in intestinal and skin epithelia (76-78). In the skin, they are mainly located in the basal epithelium of epidermis, where they represent $18-29 \%$ of T cells, but they are also present in the dermis (7-9\% of T cells) $(69,79-81)$. They express homing receptors as CCR8 and cutaneous lymphocyte-associated antigen $(78,81)$. The gut epithelium is where $V \delta 2^{\text {neg }} \gamma \delta \mathrm{T}$ cells are the most abundant. They are located in the epithelium close to the basal membrane where they represent one-third of resident $\mathrm{T}$ cells. They are also found within the lamina propria (5\% of T cells) $(76,77,82-84)$. Both skin and intestinal V $\delta 1$ repertoire are compartmentalized, with no overlap with the circulating V $\delta 1$ repertoire, suggesting these cells are resident cells $(85,86)$. However, these data are counterbalanced by observations made in cattle and sheep, showing that $\gamma \delta$ T cells could recirculate from the skin and intestinal epithelium, to the blood via afferent lymph and lymph nodes (87). Therefore in the future, the question about the localization of $V \delta 2^{\text {neg }} \gamma \delta \mathrm{T}$ cells during the anti-CMV immune response needs to be addressed to elucidate if their peripheral blood expansion reflects an expansion from CMV-injured tissues or if blood and more probably capillaries are the theater of an immunological function of these cells. Primary CMV infection in healthy individuals initiates with replication in mucosal epithelium, a leading tissue for future $V \delta 2^{\text {neg }}$ $\gamma \delta$ T cell exploration (3). Alternatively, endothelial cells, which are also the target of CMV express one of the $V \delta 2^{\text {neg }} \gamma \delta \mathrm{T}$ cell receptor (TCR) ligand identified so far, endothelial protein $\mathrm{C}$ receptor (EPCR) (see below), and as $\mathrm{V} \delta 2^{\text {neg }} \gamma \delta \mathrm{T}$ cells are retrieved in vascular beds during antibody-mediated allograft rejection (see below), microcirculation should not be disregarded in these investigations.

\section{WHEN DO THESE CELLS PARTICIPATE TO THE ANTI-CMV IMMUNE RESPONSE?}

The classical pathway for activating adaptive immune response and achieving a broad systemic immune response, starts with immature dendritic cells that capture pathogens and then mature and migrate to lymph nodes where they prime $\alpha \beta \mathrm{T}$ cells and B cells, some of which migrating back to infected tissues (88). This specific response is complemented by $\gamma \delta \mathrm{T}$ cells, which have the capability to recognize a large spectrum of stress-induced 
signals (sometimes considered as pathogen-associated-molecular patterns) and to mount local effector responses at the early stage of the immune response $(89,90)$. They act in synchrony with the innate immune cells as a sensor of self-dysregulation against infected or tumor cells, a function referred to as "lymphoid-stress surveillance" $(89,90)$. In accordance with this concept, natural and induced $\gamma \delta \mathrm{T}$ cell IL-17 responses occur within 12 and $60 \mathrm{~h}$ after stimulation, while naïve $\alpha \beta$ T cells require antigen-specific priming and take at least 5-7 days to acquire effector function (88).

In human, early kinetics of $\gamma \delta \mathrm{T}$ cell response to infections are generally difficult to depict because patients present to medical care after symptom occurrence and the time of infection is not known. In this respect, post-transplantation CMV infection is a unique context because patients can be monitored before and very early after infection. In kidney transplant recipients during primo-infection, CMV-specific CD4+ T cells are detectable in the peripheral blood 7-10 days after CMV DNAemia (42, 48). CD4+ $\mathrm{T}$ cells are critical to control virus $(44,91)$. They are followed by the production of CMV IgG and CMV-specific CD8+ T cells 20 days after DNAemia (42). Surprisingly, CMV-induced V $\delta 2^{\text {neg }}$ $\gamma \delta \mathrm{T}$ cells undergo an expansion kinetic in the peripheral blood similar to that of CMV-specific CD8 $+\mathrm{T}$ cells (92). This expansion, defined as the time necessary to reach a "plateau," although variable between patients, occurs at an average of 50 days after CMV infection (median: 45 days, min-max: 20-240 days) (93). This observation is apparently not consistent with the concept of early "lymphoid-stress surveillance." To reconcile the late kinetics of CMV-induced V $\delta 2^{\text {neg }} \gamma \delta$ T cells with the early action of other $\gamma \delta$ T cell populations, it has been proposed that $\gamma \delta \mathrm{T}$ cell populations could be divided at least in two groups: (1) innate-like cells that respond rapidly and at a relatively high frequency in many tissue sites, and (2) lymphoid-homing $\gamma \delta \mathrm{T}$ cells that may be primed in the circulation and clonally expanded in a conventional "adaptive” manner (90). Sampling being limited to blood of transplant recipients may have hampered detection of rapidly responding innate-like $\gamma \delta \mathrm{T}$ cells in CMV-infected tissues and permitted only the observation of late expanded $\gamma \delta \mathrm{T}$ cells in the blood. In the future, studies in animals should analyze concomitantly $\gamma \delta$ T cells in tissues and blood, as well as their recirculation, in order to determine if a bridge exists between innate-like $\gamma \delta$ T cells, which act at an early stage and peripheral blood CMV-induced $\gamma \delta \mathrm{T}$ cells, which expand later. What we can detect in blood does not necessarily represent what is going on in tissues or lymphoid organs.

\section{WHAT IS THE FUNCTION OF CMV-INDUCED V $\delta 2^{\text {neg }} \gamma \delta$ T CELLS?}

Like CD4+ T cells, there are many $\gamma \delta \mathrm{T}$ cell subsets with various functionalities. A large literature described their production of Th1 cytokines and their cytotoxic activity against tumor and infected cells (94-99). However, other $\gamma \delta \mathrm{T}$ cell sub-populations produce IL-4 and Th2 cytokines (100), are IL-17 natural or induced $\gamma \delta \mathrm{T}$ cells (101-103), or have characteristics of regulatory T cells (104, 105). Moreover, some $\gamma \delta \mathrm{T}$ cells can also regulate B cells and $\operatorname{IgE}$ production (100) or provide the help to rapidly generate from immature dendritic cells a pool of mature dendritic cells early during microbial invasion (106-108). Some $\gamma \delta$ T cells can differentiate into professional antigen presenting cells, capable of inducing
CD4+ T cell responses and cross-presenting soluble microbial and tumor antigens to CD8+ responder cells $(109,110)$. Human epidermal $\gamma \delta \mathrm{T}$ cells are also able to produce insulin-like growth factor 1 upon activation to control neighboring stromal cells and promote wound healing $(78,111)$. This high level of functional plasticity could explain why $\gamma \delta \mathrm{T}$ cells can be found at different locations and at different stages of the immune response.

The function of CMV-induced $\mathrm{V} \delta 2^{\text {neg }} \gamma \delta \mathrm{T}$ cells can be first understood by analyzing their phenotype. Whereas a naive phenotype is observed in $\mathrm{V} \delta 2^{\text {neg }} \gamma \delta \mathrm{T}$ cells of CMV-seronegative patients, peripheral blood CMV-induced $V \delta 2^{\text {neg }} \gamma \delta \mathrm{T}$ cells exhibit an effector/memory TEMRA phenotype, strikingly similar to and characteristic of that observed in CMV-specific CD8 $+\alpha \beta$ T cells $(112,113)$. Most of these cells are CD27-, CD28-, CD45RA+, CD45RO-, Perforin ++, Granzyme B++, CCR7-, CD62L-, and have an activated phenotype (CD69+, HLA-DR+, and but CD25-), suggesting a potential cytotoxic function against CMVinfected cells (Figure 1) $(52,64,92)$. A central/memory phenotype is observed less frequently than on CMV-specific CD8+ T cells (92, $112,113)$. The accumulation of the TEMRA CD45RA+CD27phenotype on both CMV-specific CD8 $+\mathrm{T} \alpha \beta$ cells and V $82^{\text {neg }}$ $\gamma \delta \mathrm{T}$ cells, suggests that this phenotype is induced by the virus (92, 114). Like the CD4+ CD28- $\alpha \beta$ T cells and the CD8+ CD45RA + CD27- $\alpha \beta$ T cells described by van Lier (114), the presence of CD45RA $+\mathrm{CD} 27-\mathrm{V} \delta 2^{\text {neg }} \gamma \delta \mathrm{T}$ cells can also be considered as a cell signature of a "past contact with CMV" (64). The absence of these cells in the peripheral blood of patients infected with others viruses is the witness of its peculiar CMV specificity, probably under the dependence of a specific CMV-induced stress signature.

Three quarters of CMV-induced $V \delta 2^{\text {neg }} \gamma \delta \mathrm{T}$ cells also express CD16 (Fc $\gamma$ RIIIA), which is a low-affinity receptor for Fc portion of immunoglobulin. This feature, shared with NK cells, represents a specificity of $\mathrm{V} \delta 2^{\text {neg }} \gamma \delta$ T cells when compared to CD $8 \alpha \beta$ T cells responding to CMV. CMV infection has therefore the unique capability to deeply reshape the CD16 compartment, because CD16 is only expressed by $20 \%$ of $\mathrm{V} \delta 2^{\text {neg }} \gamma \delta \mathrm{T}$ cells of CMV-seronegative patients (115). As depicted in Figure 2, CMV infection doubles the number of circulating CD16+ lymphocytes, through this

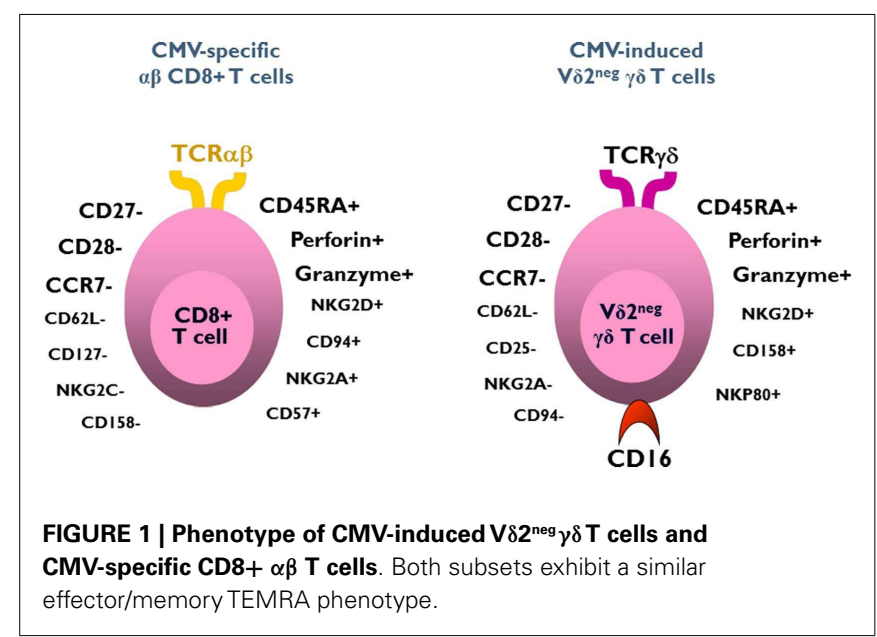




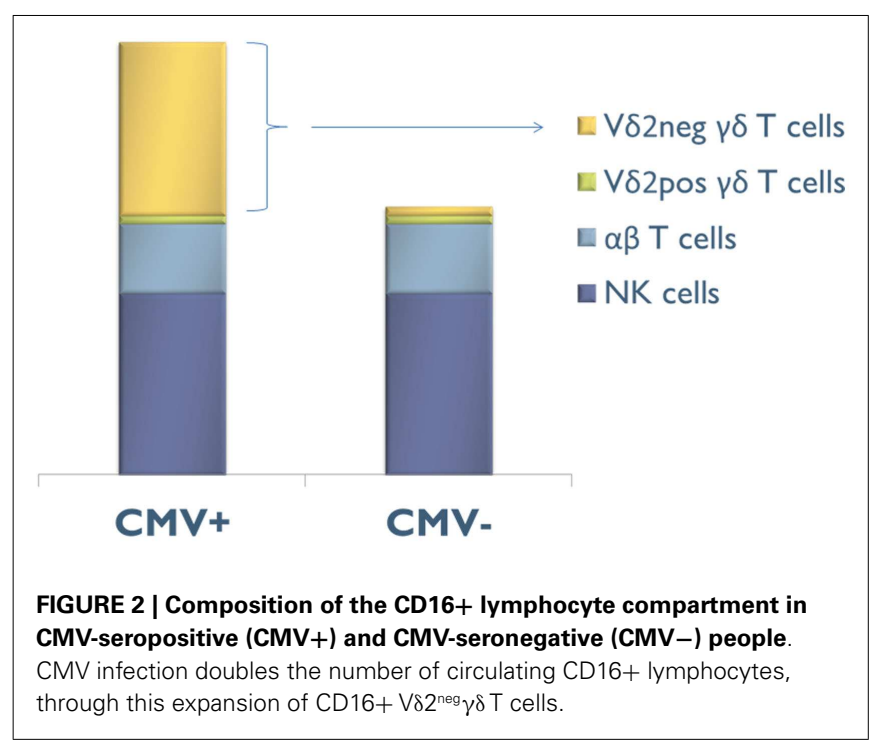

expansion of CD16 $+\mathrm{V} \delta 2^{\text {neg }} \gamma \delta \mathrm{T}$ cells. A majority of these cells also express NK receptors (NKG2D, CD158b/j, and NKp80), by contrast to CMV-specific CD8 $+\mathrm{T} \alpha \beta$ cells $(52,64,92,115,116)$. This innate-like cell phenotype probably confers to $\mathrm{V} \delta 2^{\text {neg }} \gamma \delta \mathrm{T}$ cells a mode of activation and of regulation different from that of $\alpha \beta \mathrm{T}$ cells and a non-redundant role in the control of CMV. Moreover, heterogeneity in NK receptor expression can be found within a single clone of $\mathrm{V} \delta 2^{\text {neg }} \gamma \delta \mathrm{T}$ cells. Therefore, $\mathrm{V} \delta 2^{\text {neg }} \gamma \delta \mathrm{T}$ cell clones can be a mosaic of cells with similar TCR but different activating or inhibiting susceptibility, which could regulate them differently according to the context or tissues (117). In line with this singular phenotype, $V \delta 2^{\text {neg }} \gamma \delta$ T cells can be considered at the crossroads between T cells and NK cells $(118,119)$.

In vitro, $\mathrm{V} \delta 2^{\text {neg }} \gamma \delta \mathrm{T}$ cells are activated in the presence of free IgG-opsonized CMV or of CMV-infected fibroblast lysates, but not uninfected or other herpes virus-infected fibroblast lysates (HSV or VZV) (52). In culture with CMV-infected cells or IgGopsonized human $\mathrm{CMV}, \mathrm{V} \delta 2^{\text {neg }} \gamma \delta \mathrm{T}$ cell lines or clones coming from $\mathrm{CMV}$-infected solid-organ transplant recipients produce large amounts of TNF- $\alpha$ and/or interferon- $\gamma$ (58, 59, 62, 115, 120). In vitro, this CMV-induced interferon- $\gamma$ production is able to inhibit CMV replication. $\mathrm{V} \delta 2^{\text {neg }} \gamma \delta \mathrm{T}$ cells also show perforin/granzyme B dependent cytotoxicity against CMV-infected cells in vitro $(62,120)$. All the data coming from different groups support the concept that most of the $V \delta 2^{\text {neg }} \gamma \delta \mathrm{T}$ cells share the same cytotoxic effector function as CMV-specific CD8 $+\mathrm{T} \alpha \beta$ cells $(42,49)$. However, distinct CMV-induced V $\delta 2^{\text {neg }} \gamma \delta \mathrm{T}$ cell clones can also provide the help to generate from immature dendritic cells a pool of mature dendritic cells (58).

In BALB/c mice and Sprague-Dawley rats, the number of $\gamma \delta \mathrm{T}$ cells increase after CMV infection in the draining lymph nodes, liver, peritoneal cavity, and salivary glands $(121,122) . \gamma \delta \mathrm{T}$ celldepleted mice have a significantly higher viral load after CMV infection (123). Using C57BL/ $6 \alpha \beta$ and/or $\gamma \delta$ T cell-deficient mice, we recently observed that $\gamma \delta$ T cells were as competent as $\alpha \beta$ T cells to control viral spread and murine CMV-induced disease and to protect mice from death (unpublished data).
All these in vitro indications of an anti-viral function of $\mathrm{V} \delta 2^{\text {neg }} \gamma \delta \mathrm{T}$ cells are supported in vivo by the observation that early expansion of $V \delta 2^{\text {neg }} \gamma \delta \mathrm{T}$ cells correlates with low viral loads, less symptomatic infection, and a rapid viral clearance in renal transplant patients (93).

\section{HOW DO V $\delta 2^{\text {neg }} \gamma \delta$ T CELLS RECOGNIZE CMV-INFECTED CELLS OR CMV?}

Given their large panel of activating receptors, activation of $\mathrm{V} \delta 2^{\text {neg }}$ $\gamma \delta \mathrm{T}$ cells during CMV infection may be multifactorial. We will develop here the involvement of the TCR and the CD16 molecule, which could act at different stages of the immune response. While often involved in $\gamma \delta \mathrm{T}$ cell activation, NKGD or its ligands (MICA/B and ULPB1-3) do not seem involved in this situation (120), probably because these $\gamma \delta$ T cells are selected by CMV, which is able to inhibit NKG2D-ligands surface expression on infected cells (124). Two other molecules have been shown to co-stimulate activation of CMV-induced V $\delta 2^{\text {neg }} \gamma \delta \mathrm{T}$ cells: CD8 $\alpha \alpha$ (58) and LFA-1, which recognizes up-regulation of ICAM-1 expression by CMV on infected cells (125).

\section{$\gamma \delta$ TCR}

$\mathrm{T}$ cell receptor involvement in $\mathrm{V} \delta 2^{\text {neg }} \gamma \delta \mathrm{T}$ cell reactivity against CMV-infected cells has been demonstrated by inhibition of their activation using blocking anti-TCR antibodies or through transfer of reactivity after transduction of the $\gamma \delta$ TCR in reporter cell lines $(120,125)$. Analysis of $\gamma \delta$ TCR junctional diversity shows that expansion of $\mathrm{V} \delta 1$ and $\mathrm{V} \delta 3 \mathrm{~T}$ cells during CMV infection is associated with a restricted repertoire, which is suggestive of an antigens-driven selection $(52,64)$. This was also observed in neonates infected in utero with CMV, who specifically display a preponderant expansion of a particular $\gamma \delta \mathrm{T}$ cell population expressing a public invariant $\mathrm{V} \gamma 8 \mathrm{~V} \delta 1$ TCR (62). This population has not been reported in CMV-infected adults, suggesting that it might recognize an antigen specifically induced during in utero infection or that this invariant TCR is generated only during fetal life. Recognition of CMV-infected cells by $V \delta 2^{\text {neg }} \gamma \delta$ T cells is independent of classical major histocompatibility complex (MHC) antigens, by contrast to CMV-specific $\alpha \beta$ T cells. This is consistent with the reported recognition by $\gamma \delta \mathrm{T}$ cells of structurally diverse proteins of self and microbial origins (88), and that resembles immunoglobulin-like antigen recognition (126). V 11 TCR have also been shown to recognize MHC-like molecules such as MICA/B and CD1. MICA and MICB (MHC class I chain-related proteins $A$ and $B$ ) are overexpressed in stressed cells, as in tumor or infected cells. They co-localize with V $\delta 1 \gamma \delta$ TCR in some tumors. Both $\gamma \delta$ chains are necessary for the recognition of the MICA/B $\alpha 1$ and $\alpha 2$ domains, which is independent of any loaded peptide (94, 127-129). CD1c and CD1d are non-polymorphic molecules, which present lipids and glycolipids to NKT cells $(130,131)$ and also activate $\mathrm{V} \delta 1$ and $V \delta 3 \gamma \delta \mathrm{T}$ cells $(107,132)$. Specific interaction between V $\delta 1 \gamma \delta$ TCR and CD1c molecule has been demonstrated using TCR transduction in reporter cell line, showing that no glycolipid are involved in this recognition (107). Interaction between V $\delta 1 \gamma \delta$ TCR and CD1d has also been demonstrated using tetramers, recombinants TCR, and structural studies (133-135). CD1d can be recognized by V $\delta 1 \gamma \delta$ TCR as an "unloaded" form or 
when loaded with endogenous glycosphingolipids (133-135) or exogenous phospholipids $(108,136)$.

MICA/B and CD1d are not expressed on the surface of CMVinfected cells (120) and only $0.3 \%$ of CMV-induced $V \delta 2^{\text {neg }} \gamma \delta$ $\mathrm{T}$ cells are stained with CD1d- $\alpha$ GalCer tetramers (our unpublished data), suggesting that CMV does not select for MICA/B or CD1d-specific $\mathrm{V} \delta 2^{\text {neg }} \gamma \delta \mathrm{T}$ cells. CMV-infected cells therefore offer the opportunity to discover new $\mathrm{V} \delta 2^{\text {neg }} \gamma \delta \mathrm{T}$ cell ligands. Using a strategy based on the generation of monoclonal antibodies with the same antigen specificity as the CMV-induced $V \delta 2^{\text {neg }}$ $\gamma \delta \mathrm{T}$ cells, we identified EPCR as another MHC-like ligand for a $\mathrm{V} \gamma 4 \mathrm{~V} \delta 5 \mathrm{TCR}$ (125). EPCR is a non-polymorphic protein constitutively expressed on endothelial cells and involved in the regulation of coagulation through the activation of protein C (137). It did not have any described "immunologic" function, although it displays a structural homology with CD1d (125). Recognition of EPCR by $\mathrm{V} \gamma 4 \mathrm{~V} \delta 5$ TCR is independent of glycosylation and has a binding mode that does not involve discrimination of lipid antigens. Cell infection by CMV does not increase EPCR expression and $\mathrm{V} \gamma 4 \mathrm{~V} \delta 5 \mathrm{~T}$ cell clone reactivity requires co-stimulatory molecules, which are over expressed in CMV-infected cells, such as LFA3 (CD2 ligand) and ICAM-1 (LFA-1 ligand) (Figure 3A) (128, 138-140). This constitutive expression of EPCR opens the possibility of its homeostatic interaction with $\gamma \delta$ TCR, as previously reported for mice skin epithelial $\gamma \delta \mathrm{T}$ cells and ligands expressed on keratinocytes (141). This interaction could serve either to keep tissue $\gamma \delta \mathrm{T}$ cells pre-activated and ready to swiftly engage in the immune response or to activate regulatory functions necessary for maintenance of tissue integrity at steady state. Whether such a constitutively expressed TCR ligand needs conformation, topology or molecular interaction changes at the surface of target cells to prime stress surveillance response of $\gamma \delta$ T cells deserves further investigations. Not all $V \delta 2^{\text {neg }} \gamma \delta \mathrm{T}$ cells reactive against $\mathrm{CMV}$-infected cells recognize EPCR, indicating the existence of other TCR ligands. Their characterization will be important to improve our knowledge of how cell stress and self-dysregulation are captured by $\mathrm{V} \delta 2^{\text {neg }} \gamma \delta \mathrm{T}$ cells.

\section{CD16}

As mentioned above, CMV infection is associated with the expression of CD16 at the cell surface of a large majority of circulating $\mathrm{V} \delta 2^{\text {neg }} \gamma \delta \mathrm{T}$ cells. This expression did not allow $\gamma \delta \mathrm{T}$ cells to perform antibody-dependent cell-mediated cytotoxicity (ADCC) against CMV-infected cells pre-incubated with CMV hyperimmune IgGs, probably because of the seemingly low rate of IgGs directed against CMV-infected cells in sera of infected people (115). However, even in the absence of TCR stimulation, CD16 $+\mathrm{V} \delta 2^{\text {neg }} \gamma \delta \mathrm{T}$ cells produce interferon- $\gamma$ and inhibit CMV replication when activated by IgG-opsonized free CMV, in presence of IL-12 and interferon- $\alpha$, two cytokines produced by

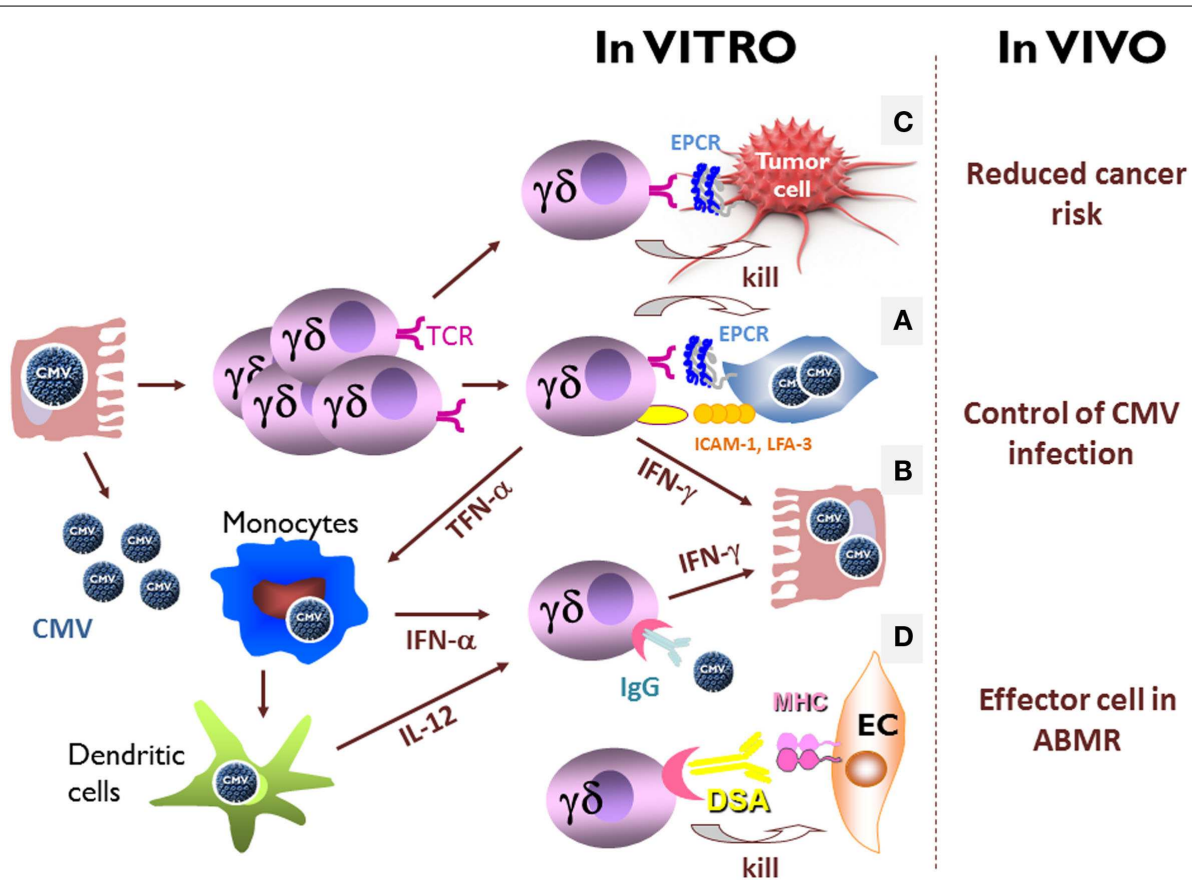

FIGURE 3 | In vitro and in vivo direct and indirect effects of CMV-induced V $\delta 2^{\text {neg }} \gamma \delta$ T cells. (A) In culture with CMV-infected cells, V $\delta 2^{\text {neg }} \gamma \delta T$ cell lines or clones coming from CMV-infected solid-organ transplant recipients produce large amounts of TNF- $\alpha$ and/or interferon- $\gamma$, and exert a strong cytotoxicity against CMV-infected cells. V $\delta 2^{\text {neg }} \gamma \delta$ T cell reactivity requires EPCR expression and co-stimulatory molecules, which are over expressed in CMV-infected cells, as LFA-3 (CD2 ligand) and ICAM-1 (LFA-1 ligand). (B) In the absence of TCR stimulation, $C D 16+V \delta 2^{\text {neg }} \gamma \delta T$ cells produce interferon- $\gamma$ and inhibit CMV replication when activate by lgG-opsonized free CMV, in presence of IL-12 and interferon- $\alpha$, two cytokines produced by monocytes/macrophages and dendritic cells during CMV infection. (C) CMV-induced $V \delta 2^{\text {neg }} \gamma \delta \mathrm{T}$ cells have a TCR-dependent cross-reactivity against CMV-infected cells and tumor cells. (D) CMV-induced CD16+V $\delta 2^{\text {neg }} \gamma \delta$ $\mathrm{T}$ cells are able to perform antibody-dependent cell-mediated cytotoxicity (ADCC) against endothelial cells (EC) coated with donor-specific antibody (DSA). Within the grafts, $\gamma \delta$ T cells are retrieved in close contact with endothelial cells in the peritubular capillaritis and glomerulitis associated with acute antibody-mediated rejection, only in CMV-experienced patients. 
monocytes/macrophages and dendritic cells during CMV infection (Figure 3B) (115). This antibody-dependent cell-mediated inhibition (ADCI) is a new function of $\mathrm{V} \delta 2^{\text {neg }} \gamma \delta \mathrm{T}$ cells in their arsenal to control the virus, where antigen specificity is mediated by the antibody and not by the TCR, and is probably controlled by the cytokine microenvironment. ADCI could be restricted to specific areas, such as CMV-infected tissues or mucosa infiltrated by activated macrophages or dendritic cells, and where $V \delta 2^{\text {neg }}$ $\gamma \delta \mathrm{T}$ cells are homing and suspected to play a pivotal role. In accordance with the late expansion of $V \delta 2^{\text {neg }} \gamma \delta \mathrm{T}$ in the blood during the infection, ADCI could be involved in the prevention of CMV reactivation by $\mathrm{V} \delta 2^{\text {neg }} \gamma \delta \mathrm{T}$ cells, when antibodies have been generated (42).

\section{UNEXPECTED ANTI-TUMOR EFFECTS OF CMV-INDUCED V $\delta 2^{\text {neg }} \gamma \delta$ T CELLS}

Because of their immunosuppressed status, the risk of cancer in kidney transplant recipients is between 2.5 and 4 times greater than in the general population, with mainly non-melanoma skin cancer (the most common type of malignancy in kidney transplant recipients), lymphoma, cancer of the lip, vulvovaginal tumors, and kidney cancers (142-145). This is consistent with the concept of cancer immunosurveillance and cancer immunoediting, which has been well characterized in recombinase-activating gene (RAG) knock-out mice (146), as well as in humans (147-150). Among the cells involved in anti-tumor immunity, $\gamma \delta \mathrm{T}$ cells are considered to play a key role (95). As a major demonstration, $\gamma \delta$ TCR knock-out mice have been shown to develop more skin cancers than wild-type mice (151). In humans, $\gamma \delta \mathrm{T}$ cells infiltrate many carcinomas and exert a strong interferon $-\gamma$ production and cytotoxicity against carcinoma cells in vitro (77, 79, 81, 94-99, 151-157). More recent studies also reported opposite results suggesting pro-tumoral functions of $\gamma \delta$ T cells both in human cancers (158) and in murine models (159-161) making the role played by the different $\gamma \delta \mathrm{T}$ cells in tumor surveillance more subtle. Nevertheless, during the past years, $\gamma \delta \mathrm{T}$ cells have been targeted in cancer immunotherapy trials showing mitigated but encouraging clinical benefit [reviewed in Ref. (162)]. It is noteworthy that all these trials uniquely targeted $\mathrm{V} \gamma 9 \mathrm{~V} \delta 2 \mathrm{~T}$ cells. Immunity to tumors may be acquired during events that have no clear relationship to cancer, and some infectious diseases have been associated with a reduced risk of cancers $(163,164)$. In line with these observations, CMV-induced $V \delta 2^{\text {neg }} \gamma \delta \mathrm{T}$ cells have a TCR-dependent crossreactivity against CMV-infected cells and tumor cells (Figure $3 \mathrm{C}$ ) $(58,120) . V \delta 2^{\text {neg }} \gamma \delta \mathrm{T}$ cell lines or clones kill tumor cells as efficiently as CMV-infected cell in vitro. Moreover, using a human tumor xenograft models in immunodeficient mouse, we observed that CMV-induced $V \delta 2^{\text {neg }} \gamma \delta \mathrm{T}$ cells could inhibit tumor growth in vivo $(165,166)$. Finally in kidney transplant recipients, high $\mathrm{CMV}$-induced $\mathrm{V} \delta 2^{\text {neg }} \gamma \delta \mathrm{T}$ cell counts as well as a past contact with CMV were associated with reduced cancer occurrence in the upcoming years (167). Taken together, these data reveal a dual role for $\mathrm{CMV}$-induced $\mathrm{V} \delta 2^{\text {neg }} \gamma \delta \mathrm{T}$ cells in kidney transplant recipients in viral control and in surveillance of subsequent malignancy. This shared reactivity against CMV-infected and tumor cells has been observed also after allogeneic stem cell transplantation (58), where CMV infection is associated with a decreased risk of acute myeloid leukemia relapse $(168,169)$, and where $\gamma \delta \mathrm{T}$ cell expansion is associated with a reduced risk of relapse (170). This potential protective role of CMV against cancer in transplant recipients has been challenged by other groups (171), and could be in apparent contrast to the previously reported presence of the CMV genome and antigens in diverse types of carcinomas $(172,173)$. However, even if $\mathrm{CMV}$ has been suggested to play a direct role in carcinogenesis, one cannot exclude that its reactivation in tumors represents an epiphenomenon due for instance to inflammation $(174,175)$. All of these studies may be consistent with our results if we assume that both CMV-infected cells and tumor cells (infected or not) express the same stress-induced molecules recognized by $\gamma \delta$ TCRs, resulting in the selection of common immune effector cells among which $V \delta 2^{\text {neg }} \gamma \delta \mathrm{T}$ cells take an important part. They also highlight the ambiguous relationships interwoven between a virus, CMV, and its host: Parasitism or symbiosis?

\section{UNEXPECTED INDIRECT EFFECT OF V $\delta 2^{\text {neg }} \gamma \delta$ T DURING ANTIBODY-MEDIATED REJECTION}

The epidemiological link observed between CMV and acute or chronic rejection is still not well understood. Many hypotheses have been proposed. CD4+ T cells of CMV-seropositive patients produce interferon- $\gamma$ and induce both MHC class II and adhesion molecules overexpression on endothelial cells, which could potentiate in situ allogeneic reaction $(176,177)$. A cross-reactivity of CMV-specific T cells against alloantigens is also discussed (178, 179). A direct CMV effect is also likely because the persistence of the virus in the blood or the kidney leads to aggressive fibrotic lesions $(26,28,180-182)$.

Recently, the importance of the recipient's humoral response against the renal allograft has been recognized to play a key role in immunological injuries contributing to graft deterioration (183191). Nowadays, antibody-mediated rejection is considered as the leading cause of graft loss on the long range (192). From an immunological point of view, donor-specific antibody (DSA)mediated lesions are considered to rely on complement-fixing DSA-mediated lysis (187), direct DSA-mediated apoptosis (193), and/or ADCC by NK cells $(194,195)$. Until recently, complement was the most recognized way leading to graft endothelial cell injury, because deposition of C4d, a breakdown product of complement component $\mathrm{C} 4$, in peritubular capillaries represented the only specific tool providing the "immunopathological evidence" of DSA interaction with graft tissue $(191,196,197)$. However, it does not encompass all DSA-mediated lesions (198). Glomerulitis and peritubular capillaritis, which are defined by an accumulation of polymorphonuclear cells, macrophages, and lymphocytes around capillaries, are associated with DSA, are more predictive of graft loss than C4d deposition $(188,199)$, and are now recognized as the main lesions of antibody-mediated rejection (200). Among these infiltrates, NK cells have recently been shown to be involved in DSA-mediated lesions of kidney microcirculation, suggesting that ADCC could play a role in DSA-mediated lesions through DSA interaction with the low-affinity Fc receptor for IgG (FcyRIIIA-CD16) expressed on NK cells (194, 195, 201). Interestingly, NK cells are not the only candidate as cell mediator of these lesions. As pointed before, CMV infection deeply reshapes the CD16+ lymphocyte compartment composition in CMV+ 
transplant recipients who exhibits an equal amount of CD16+ $\mathrm{NK}$ cells and CD16 $+\mathrm{V} \delta 2^{\text {neg }} \gamma \delta \mathrm{T}$ cells at the periphery (115). We have shown that CMV-induced CD16 $+\mathrm{V} \delta 2^{\text {neg }} \gamma \delta \mathrm{T}$ cells are able to perform ADCC against stromal cells coated with DSA in vitro (Figure 3D) (202). Within the grafts, $\gamma \delta$ T cells are found in close contact with endothelial cells in the peritubular capillaritis and glomerulitis associated with acute antibody-mediated rejection, only in CMV-experienced patients. Their localization in antibodymediated microcirculation injuries is similar to that reported for NK cells (195) and macrophages (203). Finally, an inverse correlation between a persistently increased percentage of circulating CMV-induced $\gamma \delta$ T cells and the 1-year estimated glomerular filtration rate is observed only in kidney recipients with DSA (202). $\gamma \delta \mathrm{T}$ cells are usually viewed non-alloreactive because they do not recognize peptides bound to MHC molecules. However, our recent data support the conclusion that CMV-induced CD16+ $\gamma \delta \mathrm{T}$ cells are a new player in antibody-mediated lesions of kidney transplants. As for recognition of IgG-opsonized CMV, the antigen specificity of $\gamma \delta \mathrm{T}$ cell activation relies on the antibody and not on $\gamma \delta$ TCR. Moreover, these findings suggest that $\gamma \delta \mathrm{T}$ cell ADCC could represent a new physiopathological contribution to the well-known but poorly understood association between CMV infection and the increased occurrence of rejection $(17,29)$, poor long-term graft function $(16,23,180,204)$, and low graft survival $(25,26)$.

In contrast to these data, two teams have proposed that $\mathrm{V} \delta 1 \gamma \delta \mathrm{T}$ cells play regulatory functions associated with an operational tolerance in liver transplantation (205-209). However, The Spanish team finally showed that alterations in the $\gamma \delta \mathrm{T}$ cell compartment were not restricted to tolerant liver recipients and confirmed the association between CMV infection and $\mathrm{V} \delta 1 \gamma \delta \mathrm{T}$ cell expansions (55). Most interestingly, the Japanese team described V $\delta 1 \mathrm{~T}$ cells with a public TCR infiltrating all tested tolerant liver grafts and normal livers and not found in rejected organs (209). Identification of the antigen recognized in healthy liver by this TCR could valuably contribute to decipher the mode of activation of $\gamma \delta \mathrm{T}$ cells with regulatory functions involved in preservation of tissue integrity.

Altogether, these data suggest that depending on the presence of CMV and/or DSA, $\gamma \delta \mathrm{T}$ cells could play different seemingly opposite functions on transplanted organ, which deserve further investigation in the future.

\section{CONCLUSION AND PERSPECTIVES}

In summary, numerous studies have now shown the involvement of $V \delta 2^{\text {neg }} \gamma \delta \mathrm{T}$ cells within the immune response directed against $\mathrm{CMV}$, with direct anti-viral effects, but also unexpected indirect effects in the context of kidney transplantation. Although most of the literature about $\gamma \delta \mathrm{T}$ cells considers them as actors of the innate immune response, the peripheral blood CMV-induced $\mathrm{V} \delta 2^{\text {neg }} \gamma \delta \mathrm{T}$ cells exhibit surprisingly at least three characteristics of the adaptive immunity. First like B cells, and $\alpha \beta \mathrm{T}$ cells, they use somatic rearrangement of $\mathrm{V}, \mathrm{D}$, and $\mathrm{J}$ genes to generate diverse antigen receptors (88). Secondly, they undergo monoclonal to polyclonal expansions, characterized by a variable extent of their repertoire from one patient to the other. Finally, these cells seem to have the ability to mount anamnestic responses, because they have the phenotype of effector/memory cells, and undergo a more rapid expansion during CMV reactivation than during primo-infection (64).

At the efferent phase of the immune response, their functions, activating pathways and kinetics have been better characterized. Understanding where, when and how naïve $V \delta 2^{\text {neg }} \gamma \delta \mathrm{T}$ cells are activated at the afferent phase of the CMV immune response is more challenging and will most probably require in vivo studies in animal models. The encouraging results obtained by ours and Thomas Winkler's team on the protective role of mouse $\gamma \delta \mathrm{T}$ cells against murine CMV, certainly pave the way for addressing these issues (210). Molecular understanding of how CMV-induced $\mathrm{V} \delta 2^{\text {neg }} \gamma \delta \mathrm{T}$ cells recognize CMV-infected cells and tumor cells necessitates the identification of representative antigenic ligands that could reveal valuable tools for vaccination trials targeting $\gamma \delta$ $\mathrm{T}$ cells. An alternative is the use of $\gamma \delta \mathrm{T}$ cell therapy after ex vivo expansion of $\mathrm{V} \delta 2^{\text {neg }} \gamma \delta \mathrm{T}$ cells. Interesting progress has recently been made in this direction by the teams of Laurence Cooper and John Anderson who set up conditions for clinical scale propagation of polyclonal $\gamma \delta$ T cell lines $(211,212)$.

All these basic and clinical studies are prerequisite to improve $\gamma \delta$ T cell-based immunotherapy, but a shorter term use of V $\delta 2^{\text {neg }} \gamma \delta \mathrm{T}$ cells in the clinics, will probably come from solid-organ transplantation, in which $V \delta 2^{\text {neg }} \gamma \delta \mathrm{T}$ cell monitoring could prove a useful immunological biomarker to classify patients at risk to develop CMV infection or cancer.

Moreover, transplant patients are also prone to develop other types of infections, either parasitic (with e.g., Toxoplasma gondii) or bacterial (bartonella, atypical mycobacteria), which induce $\mathrm{V} \gamma 9 \mathrm{~V} \delta 2 \mathrm{~T}$ cell expansion due to their production of phosphoantigens. Routine monitoring of $\mathrm{V} \gamma 9 \mathrm{~V} \delta 2 \mathrm{~T}$ cells in our center also allowed us in several cases during the last decade to make differential diagnosis of these infections in kidney transplant recipients.

\section{ACKNOWLEDGMENTS}

We are grateful for the technical skills provided by the technicians of the Immunology Routine Laboratory and all the nurses of the Kidney Transplantation Department (University Bordeaux Hospital). Julie Déchanet-Merville is funded by the Institut National du Cancer (Transla2013), by the Ligue Contre le Cancer, by the Agence Nationale de la Recherche (ANR-12-BVS3-0024-02), and by the Fondation pour la Recherche Médicale (DEQ20110421287).

\section{REFERENCES}

1. Evans RW, Manninen DL, Garrison LP Jr, Hart LG, Blagg CR, Gutman RA, et al. The quality of life of patients with end-stage renal disease. N Engl J Med (1985) 312:553-9. doi:10.1056/NEJM198502283120905

2. Wolfe RA, Ashby VB, Milford EL, Ojo AO, Ettenger RE, Agodoa LY, et al. Comparison of mortality in all patients on dialysis, patients on dialysis awaiting transplantation, and recipients of a first cadaveric transplant. $N$ Engl J Med (1999) 341:1725-30. doi:10.1056/NEJM199912023412303

3. Crough T, Khanna R. Immunobiology of human cytomegalovirus: from bench to bedside. Clin Microbiol Rev (2009) 22:76-98. doi:10.1128/CMR.00034-08

4. Kotton CN, Kumar D, Caliendo AM, Asberg A, Chou S, Danziger-Isakov $\mathrm{L}$, et al. Updated international consensus guidelines on the management of cytomegalovirus in solid-organ transplantation. Transplantation (2013) 96:333-60. doi:10.1097/TP.0b013e31829df29d

5. Kotton CN. CMV: prevention, diagnosis and therapy. Am J Transplant (2013) 13(Suppl 3):24-40. doi:10.1111/ajt.12006 
6. Couzi L, Helou S, Bachelet T, Martin S, Moreau K, Morel D, et al. Preemptive therapy versus valgancyclovir prophylaxis in cytomegalovirus-positive kidney transplant recipients receiving antithymocyte globulin induction. Transplant Proc (2012) 44:2809-13. doi:10.1016/j.transproceed.2012.09.029

7. McGillicuddy JW, Weimert NA, Taber DJ, Turner A, Mitchell LA, Wray DW, et al. Can preemptive cytomegalovirus monitoring be as effective as universal prophylaxis when implemented as the standard of care in patients at moderate risk? Transplantation (2010) 89:1218-23. doi:10.1097/TP.0b013e3181d54ba6

8. Walker JK, Scholz LM, Scheetz MH, Gallon LG, Kaufman DB, Rachwalski EJ, et al. Leukopenia complicates cytomegalovirus prevention after renal transplantation with alemtuzumab induction. Transplantation (2007) 83:874-82. doi:10.1097/01.tp.0000257923.69422.4d

9. Weclawiak H, Kamar N, Mengelle C, Esposito L, Mohamed AO, Lavayssiere L, et al. Pre-emptive intravenous ganciclovir versus valganciclovir prophylaxis for de novo cytomegalovirus-seropositive kidney-transplant recipients. Transpl Int (2010) 23:1056-64. doi:10.1111/j.1432-2277.2010.01101.x

10. Witzke O, Hauser IA, Bartels M, Wolf G, Wolters H, Nitschke M. Valganciclovir prophylaxis versus preemptive therapy in cytomegalovirus-positive renal allograft recipients: 1-year results of a randomized clinical trial. Transplantation (2012) 93:61-8. doi:10.1097/TP.0b013e318238dab3

11. Atabani SF, Smith C, Atkinson C, Aldridge RW, Rodriguez-Peralvarez M, Rolando N, et al. Cytomegalovirus replication kinetics in solid organ transplant recipients managed by preemptive therapy. Am J Transplant (2012) 12:2457-64. doi:10.1111/j.1600-6143.2012.04227.x

12. Couzi L, Helou S, Bachelet T, Moreau K, Martin S, Morel D, et al. High incidence of anticytomegalovirus drug resistance among D+R- kidney transplant recipients receiving preemptive therapy. Am J Transplant (2012) 12:202-9. doi:10.1111/j.1600-6143.2011.03766.x

13. Helantera I, Kyllonen L, Lautenschlager I, Salmela K, Koskinen P. Primary CMV infections are common in kidney transplant recipients after 6 months valganciclovir prophylaxis. Am J Transplant (2010) 10:2026-32. doi:10.1111/j.16006143.2010.03225.x

14. Humar A, Lebranchu Y, Vincenti F, Blumberg EA, Punch JD, Limaye AP, et al. The efficacy and safety of 200 days valganciclovir cytomegalovirus prophylaxis in high-risk kidney transplant recipients. Am J Transplant (2010) 10:1228-37. doi:10.1111/j.1600-6143.2010.03074.x

15. Khoury JA, Storch GA, Bohl DL, Schuessler RM, Torrence SM, Lockwood M, et al. Prophylactic versus preemptive oral valganciclovir for the management of cytomegalovirus infection in adult renal transplant recipients. Am J Transplant (2006) 6:2134-43. doi:10.1111/j.1600-6143.2006.01413.x

16. Kliem V, Fricke L, Wollbrink T, Burg M, Radermacher J, Rohde F. Improvement in long-term renal graft survival due to CMV prophylaxis with oral ganciclovir: results of a randomized clinical trial. Am J Transplant (2008) 8:975-83. doi:10.1111/j.1600-6143.2007.02133.x

17. Reischig T, Jindra P, Hes O, Svecova M, Klaboch J, Treska V. Valacyclovir prophylaxis versus preemptive valganciclovir therapy to prevent cytomegalovirus disease after renal transplantation. Am J Transplant (2008) 8:69-77.

18. van der Beek MT, Berger SP, Vossen AC, van der Blij-de Brouwer CS, Press RR, de Fijter JW, et al. Preemptive versus sequential prophylactic-preemptive treatment regimens for cytomegalovirus in renal transplantation: comparison of treatment failure and antiviral resistance. Transplantation (2010) 89:320-6. doi:10.1097/TP.0b013e3181bc0301

19. Lurain NS, Chou S. Antiviral drug resistance of human cytomegalovirus. Clin Microbiol Rev (2010) 23:689-712. doi:10.1128/CMR.00009-10

20. Drew WL, Paya CV, Emery V. Cytomegalovirus (CMV) resistance to antivirals. Am J Transplant (2001) 1:307-12. doi:10.1034/j.1600-6143.2001.10403.x

21. Eid AJ, Arthurs SK, Deziel PJ, Wilhelm MP, Razonable RR. Emergence of drug-resistant cytomegalovirus in the era of valganciclovir prophylaxis: therapeutic implications and outcomes. Clin Transplant (2008) 22:162-70. doi:10.1111/j.1399-0012.2007.00761.x

22. Freeman RB Jr. The 'indirect' effects of cytomegalovirus infection. Am J Transplant (2009) 9:2453-8. doi:10.1111/j.1600-6143.2009.02824.x

23. Humar A, Gillingham KJ, Payne WD, Dunn DL, Sutherland DE, Matas AJ. Association between cytomegalovirus disease and chronic rejection in kidney transplant recipients. Transplantation (1999) 68:1879-83. doi:10.1097/ 00007890-199912270-00011

24. Nett PC, Heisey DM, Fernandez LA, Sollinger HW, Pirsch JD. Association of cytomegalovirus disease and acute rejection with graft loss in kidney transplantation. Transplantation (2004) 78:1036-41. doi:10.1097/01. TP.0000137105.92464.F3

25. Sagedal S, Hartmann A, Nordal KP, Osnes K, Leivestad T, Foss A, et al. Impact of early cytomegalovirus infection and disease on long-term recipient and kidney graft survival. Kidney Int (2004) 66:329-37. doi:10.1111/j.1523-1755.2004. 00735.x

26. Helantera I, Koskinen P, Finne P, Loginov R, Kyllonen L, Salmela K, et al. Persistent cytomegalovirus infection in kidney allografts is associated with inferior graft function and survival. Transpl Int (2006) 19:893-900. doi:10.1111/j.14322277.2006.00364.x

27. Luan FL, Kommareddi M, Ojo AO. Impact of cytomegalovirus disease in $d+/ r$ kidney transplant patients receiving 6 months low-dose valganciclovir prophylaxis. Am J Transplant (2011) 11:1936-42. doi:10.1111/j.1600-6143.2011. 03611.x

28. Reischig T, Hribova P, Jindra P, Hes O, Bouda M, Treska V, et al. Long-term outcomes of pre-emptive valganciclovir compared with valacyclovir prophylaxis for prevention of cytomegalovirus in renal transplantation. J Am Soc Nephrol (2012) 23:1588-97. doi:10.1681/ASN.2012010100

29. Pouteil-Noble C, Ecochard R, Landrivon G, Donia-Maged A, Tardy JC, Bosshard S, et al. Cytomegalovirus infection - an etiological factor for rejection? A prospective study in 242 renal transplant patients. Transplantation (1993) 55:851-7. doi:10.1097/00007890-199304000-00032

30. Sagedal S, Nordal KP, Hartmann A, Sund S, Scott H, Degre M, et al. The impact of cytomegalovirus infection and disease on rejection episodes in renal allograft recipients. Am J Transplant (2002) 2:850-6. doi:10.1034/j.1600-6143. 2002.20907.x

31. Toupance O, Bouedjoro-Camus MC, Carquin J, Novella JL, Lavaud S, Wynckel A, et al. Cytomegalovirus-related disease and risk of acute rejection in renal transplant recipients: a cohort study with case-control analyses. Transpl Int (2000) 13:413-9. doi:10.1111/j.1432-2277.2000.tb01019.x

32. George MJ, Snydman DR, Werner BG, Griffith J, Falagas ME, Dougherty NN, et al. The independent role of cytomegalovirus as a risk factor for invasive fungal disease in orthotopic liver transplant recipients. Boston Center for Liver Transplantation CMVIG-Study Group. Cytogam, MedImmune, Inc. Gaithersburg, Maryland. Am J Med (1997) 103:106-13. doi:10.1016/S0002-9343(97) 80021-6

33. Falagas ME, Snydman DR, Griffith J, Werner BG. Exposure to cytomegalovirus from the donated organ is a risk factor for bacteremia in orthotopic liver transplant recipients. Boston Center for Liver Transplantation CMVIG Study Group. Clin Infect Dis (1996) 23:468-74. doi:10.1093/clinids/23.3.468

34. Chopra KB, Demetris AJ, Blakolmer K, Dvorchik I, Laskus T, Wang LF, et al. Progression of liver fibrosis in patients with chronic hepatitis $\mathrm{C}$ after orthotopic liver transplantation. Transplantation (2003) 76:1487-91. doi:10.1097/ 01.TP.0000088668.28950.7C

35. Humar A, Asberg A, Kumar D, Hartmann A, Moussa G, Jardine A, et al. An assessment of herpesvirus co-infections in patients with CMV disease: correlation with clinical and virologic outcomes. Am J Transplant (2009) 9:374-81. doi:10.1111/j.1600-6143.2008.02501.x

36. Courivaud C, Bamoulid J, Chalopin JM, Gaiffe E, Tiberghien P, Saas P, et al. Cytomegalovirus exposure and cardiovascular disease in kidney transplant recipients. J Infect Dis (2013) 207:1569-75. doi:10.1093/infdis/jit064

37. Hjelmesaeth J, Sagedal S, Hartmann A, Rollag H, Egeland T, Hagen M, et al. Asymptomatic cytomegalovirus infection is associated with increased risk of new-onset diabetes mellitus and impaired insulin release after renal transplantation. Diabetologia (2004) 47:1550-6. doi:10.1007/s00125-004-1499-z

38. Hjelmesaeth J, Muller F, Jenssen T, Rollag H, Sagedal S, Hartmann A. Is there a link between cytomegalovirus infection and new-onset posttransplantation diabetes mellitus? Potential mechanisms of virus induced beta-cell damage. Nephrol Dial Transplant (2005) 20:2311-5. doi:10.1093/ndt/gfi033

39. Pouria S, State OI, Wong W, Hendry BM. CMV infection is associated with transplant renal artery stenosis. QJM (1998) 91:185-9. doi:10.1093/qjmed/91. 3.185

40. Audard V, Matignon M, Hemery F, Snanoudj R, Desgranges P, Anglade MC, et al. Risk factors and long-term outcome of transplant renal artery stenosis in adult recipients after treatment by percutaneous transluminal angioplasty. Am J Transplant (2006) 6:95-9. doi:10.1111/j.1600-6143.2005.01136.x

41. Opelz G, Daniel V, Naujokat C, Fickenscher H, Dohler B. Effect of cytomegalovirus prophylaxis with immunoglobulin or with antiviral drugs on 
post-transplant non-Hodgkin lymphoma: a multicentre retrospective analysis. Lancet Oncol (2007) 8:212-8. doi:10.1016/S1470-2045(07)70040-2

42. Gamadia LE, Remmerswaal EB, Weel JF, Bemelman F, van Lier RA, Ten Berge IJ. Primary immune responses to human CMV: a critical role for IFN-gammaproducing CD4+ T cells in protection against CMV disease. Blood (2003) 101:2686-92. doi:10.1182/blood-2002-08-2502

43. Gamadia LE, Rentenaar RJ, Baars PA, Remmerswaal EB, Surachno S, Weel JF, et al. Differentiation of cytomegalovirus-specific CD8(+) T cells in healthy and immunosuppressed virus carriers. Blood (2001) 98:754-61. doi:10.1182/blood. V98.3.754

44. Sester M, Sester U, Gartner B, Heine G, Girndt M, Mueller-Lantzsch N, et al. Levels of virus-specific CD4 $\mathrm{T}$ cells correlate with cytomegalovirus control and predict virus-induced disease after renal transplantation. Transplantation (2001) 71:1287-94. doi:10.1097/00007890-200105150-00018

45. Sester M, Sester U, Gartner BC, Girndt M, Meyerhans A, Kohler H. Dominance of virus-specific CD8 T cells in human primary cytomegalovirus infection. $J$ Am Soc Nephrol (2002) 13:2577-84. doi:10.1097/01.ASN.0000030141.41726.52

46. Sester U, Gartner BC, Wilkens H, Schwaab B, Wossner R, Kindermann I, et al. Differences in CMV-specific T-cell levels and long-term susceptibility to CMV infection after kidney, heart and lung transplantation. Am J Transplant (2005) 5:1483-9. doi:10.1111/j.1600-6143.2005.00871.x

47. Sester U, Presser D, Dirks J, Gartner BC, Kohler H, Sester M. PD-1 expression and IL-2 loss of cytomegalovirus- specific T cells correlates with viremia and reversible functional anergy. Am J Transplant (2008) 8:1486-97. doi:10.1111/j. 1600-6143.2008.02279.x

48. Rentenaar RJ, Gamadia LE, van DerHoek N, van Diepen FN, Boom R, Weel JF, et al. Development of virus-specific CD4(+) T cells during primary cytomegalovirus infection. J Clin Invest (2000) 105:541-8. doi:10.1172/ JCI8229

49. Cobbold M, Khan N, Pourgheysari B, Tauro S, McDonald D, Osman H, et al. Adoptive transfer of cytomegalovirus-specific CTL to stem cell transplant patients after selection by HLA-peptide tetramers. J Exp Med (2005) 202:379-86. doi:10.1084/jem.20040613

50. Egli A, Humar A, Kumar D. State-of-the-art monitoring of cytomegalovirusspecific cell-mediated immunity after organ transplant: a primer for the clinician. Clin Infect Dis (2012) 55:1678-89. doi:10.1093/cid/cis818

51. Dechanet J, Merville P, Berge F, Bone-Mane G, Taupin JL, Michel P, et al. Major expansion of gammadelta $\mathrm{T}$ lymphocytes following cytomegalovirus infection in kidney allograft recipients. J Infect Dis (1999) 179:1-8. doi:10.1086/314568

52. Dechanet J, Merville P, Lim A, Retiere C, Pitard V, Lafarge X, et al. Implication of gammadelta $\mathrm{T}$ cells in the human immune response to cytomegalovirus. J Clin Invest (1999) 103:1437-49. doi:10.1172/JCI5409

53. Dechanet J, Merville P, Pitard V, Lafarge X, Moreau JF. Human gammadelta T cells and viruses. Microbes Infect (1999) 1:213-7. doi:10.1016/S1286-4579(99) 80036-7

54. Couzi L, Lafarge X, Pitard V, Neau-Cransac M, Dromer C, Billes MA, et al. Gamma-delta $\mathrm{T}$ cell expansion is closely associated with cytomegalovirus infection in all solid organ transplant recipients. Transpl Int (2010) 24:e40-2. doi:10.1111/j.1432-2277.2010.01181.x

55. Puig-Pey I, Bohne F, Benitez C, Lopez M, Martinez-Llordella M, Oppenheimer $\mathrm{F}$, et al. Characterization of gammadelta $\mathrm{T}$ cell subsets in organ transplantation. Transpl Int (2010) 23:1045-55. doi:10.1111/j.1432-2277.2010.01095.x

56. Roux A, Mourin G, Larsen M, Fastenackels S, Urrutia A, Gorochov G, et al. Differential impact of age and cytomegalovirus infection on the gammadelta $T$ cell compartment. J Immunol (2013) 191:1300-6. doi:10.4049/jimmunol.1202940

57. Prinz I, Thamm K, Port M, Weissinger EM, Stadler M, Gabaev I, et al. Donor Vdelta1+ gammadelta $\mathrm{T}$ cells expand after allogeneic hematopoietic stem cell transplantation and show reactivity against CMV-infected cells but not against progressing B-CLL. Exp Hematol Oncol (2013) 2:14. doi:10.1186/21623619-2-14

58. Scheper W, van Dorp S, Kersting S, Pietersma F, Lindemans C, Hol S, et al. gammadeltaT cells elicited by CMV reactivation after allo-SCT cross-recognize CMV and leukemia. Leukemia (2013) 27:1328-38. doi:10.1038/leu.2012.374

59. Knight A, Madrigal AJ, Grace S, Sivakumaran J, Kottaridis P, Mackinnon S, et al. The role of Vdelta2-negative gamma-delta T cells during cytomegalovirus reactivation in recipients of allogeneic stem cell transplants. Blood (2010) 116:2164-72. doi:10.1182/blood-2010-01-255166

60. de Villartay JP, Lim A, Al-Mousa H, Dupont S, Dechanet-Merville J, CoumauGatbois E, et al. A novel immunodeficiency associated with hypomorphic
RAG1 mutations and CMV infection. J Clin Invest (2005) 115:3291-9. doi: $10.1172 /$ JCI25178

61. Ehl S, Schwarz K, Enders A, Duffner U, Pannicke U, Kuhr J, et al. A variant of SCID with specific immune responses and predominance of gamma delta $\mathrm{T}$ cells. J Clin Invest (2005) 115:3140-8. doi:10.1172/JCI25221

62. Vermijlen D, Brouwer M, Donner C, Liesnard C, Tackoen M, Van Rysselberge $\mathrm{M}$, et al. Human cytomegalovirus elicits fetal gammadelta $\mathrm{T}$ cell responses in utero. J Exp Med (2010) 207:807-21. doi:10.1084/jem.20090348

63. Fornara C, Lilleri D, Revello MG, Furione M, Zavattoni M, Lenta E, et al. Kinetics of effector functions and phenotype of virus-specific and gammadelta $\mathrm{T}$ lymphocytes in primary human cytomegalovirus infection during pregnancy. J Clin Immunol (2011) 31:1054-64. doi:10.1007/s10875-011-9577-8

64. Pitard V, Roumanes D, Lafarge X, Couzi L, Garrigue I, Lafon ME, et al. Long term expansion of effector/memory $\mathrm{V} \delta 2 \mathrm{neg} \gamma \delta \mathrm{T}$ cells is a specific blood signature of CMV infection. Blood (2008) 112:1317-24. doi:10.1182/blood-200801- 136713

65. Sylwester AW, Mitchell BL, Edgar JB, Taormina C, Pelte C, Ruchti F, et al. Broadly targeted human cytomegalovirus-specific CD4+ and CD8+ T cells dominate the memory compartments of exposed subjects. J Exp Med (2005) 202:673-85. doi:10.1084/jem.20050882

66. Khan N, Hislop A, Gudgeon N, Cobbold M, Khanna R, Nayak L, et al. Herpesvirus-specific CD8 T cell immunity in old age: cytomegalovirus impairs the response to a coresident EBV infection. J Immunol (2004) 173:7481-9. doi:10.4049/jimmunol.173.12.7481

67. Ongradi J, Kovesdi V. Factors that may impact on immunosenescence: an appraisal. Immun Ageing (2010) 7:7. doi:10.1186/1742-4933-7-7

68. Falini B, Flenghi L, Pileri S, Pelicci P, Fagioli M, Martelli MF, et al. Distribution of $\mathrm{T}$ cells bearing different forms of the T cell receptor gamma/delta in normal and pathological human tissues. J Immunol (1989) 143:2480-8.

69. Groh V, Porcelli S, Fabbi M, Lanier LL, Picker LJ, Anderson T, et al. Human lymphocytes bearing $\mathrm{T}$ cell receptor gamma/delta are phenotypically diverse and evenly distributed throughout the lymphoid system. J Exp Med (1989) 169:1277-94. doi:10.1084/jem.169.4.1277

70. Bucy RP, Chen CL, Cooper MD. Tissue localization and CD8 accessory molecule expression of T gamma delta cells in humans. J Immunol (1989) 142:3045-9.

71. Lanier LL, Ruitenberg J, Bolhuis RL, Borst J, Phillips JH, Testi R. Structural and serological heterogeneity of gamma/delta $\mathrm{T}$ cell antigen receptor expression in thymus and peripheral blood. Eur J Immunol (1988) 18:1985-92. doi:10.1002/eji.1830181218

72. Bordessoule D, Gaulard P, Mason DY. Preferential localisation of human lymphocytes bearing gamma delta $\mathrm{T}$ cell receptors to the red pulp of the spleen. J Clin Pathol (1990) 43:461-4. doi:10.1136/jcp.43.6.461

73. Seki S, Abo T, Masuda T, Ohteki T, Kanno A, Takeda K, et al. Identification of activated $\mathrm{T}$ cell receptor gamma delta lymphocytes in the liver of tumor-bearing hosts. J Clin Invest (1990) 86:409-15. doi:10.1172/JCI114726

74. Hata K, Zhang XR, Iwatsuki S, Van Thiel DH, Herberman RB, Whiteside TL. Isolation, phenotyping, and functional analysis of lymphocytes from human liver. Clin Immunol Immunopathol (1990) 56:401-19. doi:10.1016/ 0090-1229(90)90160-R

75. Norris S, Collins C, Doherty DG, Smith F, McEntee G, Traynor O, et al. Resident human hepatic lymphocytes are phenotypically different from circulating lymphocytes. J Hepatol (1998) 28:84-90. doi:10.1016/S0168-8278(98)80206-7

76. Deusch K, Luling F, Reich K, Classen M, Wagner H, Pfeffer K. A major fraction of human intraepithelial lymphocytes simultaneously expresses the gamma/delta $\mathrm{T}$ cell receptor, the CD8 accessory molecule and preferentially uses the V delta 1 gene segment. Eur J Immunol (1991) 21:1053-9. doi:10.1002/eji.1830210429

77. Maeurer MJ, Martin D, Walter W, Liu K, Zitvogel L, Halusczcak K, et al. Human intestinal Vdelta 1+ lymphocytes recognize tumor cells of epithelial origin. J Exp Med (1996) 183:1681-96. doi:10.1084/jem.183.4.1681

78. Toulon A, Breton L, Taylor KR, Tenenhaus M, Bhavsar D, Lanigan C, et al. A role for human skin-resident T cells in wound healing. J Exp Med (2009) 206:743-50. doi:10.1084/jem.20081787

79. Alaibac M, Morris J, Yu R, Chu AC. T lymphocytes bearing the gamma delta T-cell receptor: a study in normal human skin and pathological skin conditions. Br J Dermatol (1992) 127:458-62. doi:10.1111/j.1365-2133.1992.tb14840.x

80. Bos JD, Teunissen MB, Cairo I, Krieg SR, Kapsenberg ML, Das PK, et al. T-cell receptor gamma delta bearing cells in normal human skin. J Invest Dermatol (1990) 94:37-42. doi:10.1111/1523-1747.ep12873333 
81. Ebert LM, Meuter S, Moser B. Homing and function of human skin gammadelta T cells and NK cells: relevance for tumor surveillance. J Immunol (2006) 176:4331-6. doi:10.4049/jimmunol.176.7.4331

82. Ullrich R, Schieferdecker HL, Ziegler K, Riecken EO, Zeitz M. Gamma delta $\mathrm{T}$ cells in the human intestine express surface markers of activation and are preferentially located in the epithelium. Cell Immunol (1990) 128:619-27. doi:10.1016/0008-8749(90)90053-T

83. Jarry A, Cerf-Bensussan N, Brousse N, Selz F, Guy-Grand D. Subsets of CD3+ (T cell receptor alpha/beta or gamma/delta) and CD3- lymphocytes isolated from normal human gut epithelium display phenotypical features different from their counterparts in peripheral blood. Eur J Immunol (1990) 20:1097-103. doi:10.1002/eji.1830200523

84. Peyrat MA, Davodeau F, Houde I, Romagne F, Necker A, Leget C, et al. Repertoire analysis of human peripheral blood lymphocytes using a human V delta 3 region-specific monoclonal antibody. Characterization of dual $\mathrm{T}$ cell receptor (TCR) delta-chain expressors and alpha beta T cells expressing V delta $3 \mathrm{~J}$ alpha C alpha-encoded TCR chains. J Immunol (1995) 155:3060-7.

85. Chowers Y, Holtmeier W, Harwood J, Morzycka-Wroblewska E, Kagnoff MF. The V delta $1 \mathrm{~T}$ cell receptor repertoire in human small intestine and colon. $J$ Exp Med (1994) 180:183-90. doi:10.1084/jem.180.1.183

86. Holtmeier W, Chowers Y, Lumeng A, Morzycka-Wroblewska E, Kagnoff MF. The delta $\mathrm{T}$ cell receptor repertoire in human colon and peripheral blood is oligoclonal irrespective of V region usage. J Clin Invest (1995) 96:1108-17. doi:10.1172/JCI118097

87. Shekhar S, Milling S, Yang X. Migration of gammadelta T cells in steady-state conditions. Vet Immunol Immunopathol (2012) 147:1-5. doi:10.1016/j.vetimm. 2012.03 .016

88. Chien YH, Meyer C, Bonneville M. Gammadelta T cells: first line of defense and beyond. Annu Rev Immunol (2014) 32:121-55. doi:10.1146/annurevimmunol-032713-120216

89. Hayday AC. Gammadelta T cells and the lymphoid stress-surveillance response. Immunity (2009) 31:184-96. doi:10.1016/j.immuni.2009.08.006

90. Vantourout P, Hayday A. Six-of-the-best: unique contributions of gammadelta T cells to immunology. Nat Rev Immunol (2013) 13:88-100. doi:10.1038/ nri3384

91. Gabanti E, Bruno F, Lilleri D, Fornara C, Zelini P, Cane I, et al. Human cytomegalovirus (HCMV)-specific CD4+ and CD8+ T cells are both required for prevention of HCMV disease in seropositive solid-organ transplant recipients. PLoS One (2014) 9:e106044. doi:10.1371/journal.pone.0106044

92. Couzi L, Pitard V, Netzer S, Garrigue I, Lafon ME, Moreau JF, et al. Common features of gammadelta $\mathrm{T}$ cells and $\mathrm{CD} 8(+)$ alphabeta $\mathrm{T}$ cells responding to human cytomegalovirus infection in kidney transplant recipients. J Infect Dis (2009) 200:1415-24. doi:10.1086/644509

93. Lafarge X, Merville P, Cazin MC, Berge F, Potaux L, Moreau JF, et al. Cytomegalovirus infection in transplant recipients resolves when circulating gammadelta $\mathrm{T}$ lymphocytes expand, suggesting a protective antiviral role. J Infect Dis (2001) 184:533-41. doi:10.1086/322843

94. Groh V, Rhinehart R, Secrist H, Bauer S, Grabstein KH, Spies T. Broad tumor-associated expression and recognition by tumor-derived gamma delta T cells of MICA and MICB. Proc Natl Acad Sci U S A (1999) 96:6879-84. doi:10.1073/pnas.96.12.6879

95. Ferrarini M, Ferrero E, Dagna L, Poggi A, Zocchi MR. Human gammadelta T cells: a nonredundant system in the immune-surveillance against cancer. Trends Immunol (2002) 23:14-8. doi:10.1016/S1471-4906(01)02110-X

96. Zocchi MR, Ferrarini M, Rugarli C. Selective lysis of the autologous tumor by delta TCS1+ gamma/delta+ tumor-infiltrating lymphocytes from human lung carcinomas. Eur J Immunol (1990) 20:2685-9. doi:10.1002/eji. 1830201224

97. Zocchi MR, Ferrarini M, Migone N, Casorati G. T-cell receptor V delta gene usage by tumour reactive gamma delta $\mathrm{T}$ lymphocytes infiltrating human lung cancer. Immunology (1994) 81:234-9.

98. Ferrarini M, Heltai S, Pupa SM, Mernard S, Zocchi R. Killing of laminin receptor-positive human lung cancers by tumor infiltrating lymphocytes bearing gammadelta(+) t-cell receptors. J Natl Cancer Inst (1996) 88:436-41. doi:10.1093/jnci/88.7.436

99. Poggi A, Venturino C, Catellani S, Clavio M, Miglino M, Gobbi M, et al. Vdeltal T lymphocytes from B-CLL patients recognize ULBP3 expressed on leukemic B cells and up-regulated by trans-retinoic acid. Cancer Res (2004) 64:9172-9. doi:10.1158/0008-5472.CAN-04-2417
100. Wen L, Barber DF, Pao W, Wong FS, Owen MJ, Hayday A. Primary gamma delta cell clones can be defined phenotypically and functionally as Th1/Th2 cells and illustrate the association of CD4 with Th2 differentiation. J Immunol (1998) 160:1965-74.

101. Shibata K, Yamada H, Nakamura R, Sun X, Itsumi M, Yoshikai Y. Identification of CD25+ gamma delta $\mathrm{T}$ cells as fetal thymus-derived naturally occurring IL-17 producers. J Immunol (2008) 181:5940-7. doi:10.4049/jimmunol.181.9. 5940

102. Hamada S, Umemura M, Shiono T, Tanaka K, Yahagi A, Begum MD, et al. IL-17A produced by gammadelta $\mathrm{T}$ cells plays a critical role in innate immunity against listeria monocytogenes infection in the liver. J Immunol (2008) 181:3456-63. doi:10.4049/jimmunol.181.5.3456

103. Hamada S, Umemura M, Shiono T, Hara H, Kishihara K, Tanaka K, et al. Importance of murine Vdeltalgammadelta $\mathrm{T}$ cells expressing interferon-gamma and interleukin-17A in innate protection against Listeria monocytogenes infection. Immunology (2008) 125:170-7. doi:10.1111/j.1365-2567.2008.02841.x

104. Peng G, Wang HY, Peng W, Kiniwa Y, Seo KH, Wang RF. Tumor-infiltrating gammadelta $\mathrm{T}$ cells suppress $\mathrm{T}$ and dendritic cell function via mechanisms controlled by a unique toll-like receptor signaling pathway. Immunity (2007) 27:334-48. doi:10.1016/j.immuni.2007.05.020

105. Bhagat G, Naiyer AJ, Shah JG, Harper J, Jabri B, Wang TC, et al. Small intestinal CD8+TCRgammadelta+NKG2A+ intraepithelial lymphocytes have attributes of regulatory cells in patients with celiac disease. J Clin Invest (2008) 118:281-93. doi:10.1172/JCI30989

106. Leslie DS, Vincent MS, Spada FM, Das H, Sugita M, Morita CT, et al. CD1mediated gamma/delta T cell maturation of dendritic cells. J Exp Med (2002) 196:1575-84. doi:10.1084/jem.20021515

107. Spada FM, Grant EP, Peters PJ, Sugita M, Melian A, Leslie DS, et al. Selfrecognition of CD1 by gamma/delta T cells: implications for innate immunity. J Exp Med (2000) 191:937-48. doi:10.1084/jem.191.6.937

108. Russano AM, Bassotti G, Agea E, Bistoni O, Mazzocchi A, Morelli A, et al. CD1-restricted recognition of exogenous and self-lipid antigens by duodenal gammadelta+ T lymphocytes. J Immunol (2007) 178:3620-6. doi:10.4049/ jimmunol.178.6.3620

109. Brandes M, Willimann K, Bioley G, Levy N, Eberl M, Luo M, et al. Crosspresenting human gammadelta $\mathrm{T}$ cells induce robust CD8+ alphabeta $\mathrm{T}$ cell responses. Proc Natl Acad Sci U S A (2009) 106:2307-12. doi:10.1073/pnas. 0810059106

110. Brandes M, Willimann K, Moser B. Professional antigen-presentation function by human gammadelta T Cells. Science (2005) 309:264-8. doi:10.1126/science. 1110267

111. Jameson J, Havran WL. Skin gammadelta T-cell functions in homeostasis and wound healing. Immunol Rev (2007) 215:114-22. doi:10.1111/j.1600-065X. 2006.00483.x

112. Kuijpers TW, Vossen MT, Gent MR, Davin JC, Roos MT, Wertheim-van Dillen PM, et al. Frequencies of circulating cytolytic, CD45RA+CD27-, CD8+ T lymphocytes depend on infection with CMV. J Immunol (2003) 170:4342-8. doi:10.4049/jimmunol.170.8.4342

113. Appay V, Dunbar PR, Callan M, Klenerman P, Gillespie GM, Papagno L, et al. Memory CD8+ T cells vary in differentiation phenotype in different persistent virus infections. Nat Med (2002) 8:379-85. doi:10.1038/nm0402-379

114. van de Berg PJ, van Stijn A, Ten Berge IJ, van Lier RA. A fingerprint left by cytomegalovirus infection in the human $\mathrm{T}$ cell compartment. J Clin Virol (2008) 41:213-7. doi:10.1016/j.jcv.2007.10.016

115. Couzi L, Pitard V, Sicard X, Garrigue I, Hawchar O, Merville P, et al. Antibody-dependent anti-cytomegalovirus activity of human gammadelta $\mathrm{T}$ cells expressing CD16 (FcgammaRIIIa). Blood (2012) 119:1418-27. doi:10. 1182/blood-2011-06-363655

116. van Stijn A, Rowshani AT, Yong SL, Baas F, Roosnek E, Ten Berge IJ, et al. Human cytomegalovirus infection induces a rapid and sustained change in the expression of NK cell receptors on CD8+ T cells. J Immunol (2008) 180:4550-60. doi:10.4049/jimmunol.180.7.4550

117. Lafarge X, Pitard V, Ravet S, Roumanes D, Halary F, Dromer C, et al. Expression of MHC class I receptors confers functional intraclonal heterogeneity to a reactive expansion of gammadelta T cells. Eur J Immunol (2005) 35:1896-905. doi:10.1002/eji.200425837

118. Kalyan S, Kabelitz D. Defining the nature of human gammadelta T cells: a biographical sketch of the highly empathetic. Cell Mol Immunol (2013) 10:21-9. doi:10.1038/cmi.2012.44 
119. Nabekura T, Lanier LL. Antigen-specific expansion and differentiation of natural killer cells by alloantigen stimulation. J Exp Med (2014) 211:2455-65. doi:10.1084/jem.20140798

120. Halary F, Pitard V, Dlubek D, Krzysiek R, de la Salle H, Merville P, et al. Shared reactivity of $\mathrm{V}\{$ delta $2($ neg) \{gamma\}\{delta\} $\mathrm{T}$ cells against cytomegalovirus-infected cells and tumor intestinal epithelial cells. J Exp Med (2005) 201:1567-78. doi:10.1084/jem.20041851

121. Cavanaugh VJ, Deng Y, Birkenbach MP, Slater JS, Campbell AE. Vigorous innate and virus-specific cytotoxic T-lymphocyte responses to murine cytomegalovirus in the submaxillary salivary gland. J Virol (2003) 77:1703-17. doi:10.1128/JVI.77.3.1703-1717.2003

122. Dyugovskaya L, Hirsh M, Ginsburg H. Phenotypic profile and functional characterization of rat lymph node-derived gammadelta $\mathrm{T}$ cells: implication in the immune response to cytomegalovirus. Immunology (2003) 108:129-36. doi:10.1046/j.1365-2567.2003.01568.x

123. Ninomiya T, Takimoto H, Matsuzaki G, Hamano S, Yoshida H, Yoshikai Y, et al. Vgamma1+ gammadelta $\mathrm{T}$ cells play protective roles at an early phase of murine cytomegalovirus infection through production of interferon-gamma. Immunology (2000) 99:187-94. doi:10.1046/j.1365-2567.2000.00938.x

124. Slavuljica I, Krmpotic A, Jonjic S. Manipulation of NKG2D ligands by cytomegaloviruses: impact on innate and adaptive immune response. Front Immunol (2011) 2:85. doi:10.3389/fimmu.2011.00085

125. Willcox CR, Pitard V, Netzer S, Couzi L, Salim M, Silberzahn T, et al. Cytomegalovirus and tumor stress surveillance by binding of a human gammadelta $\mathrm{T}$ cell antigen receptor to endothelial protein $\mathrm{C}$ receptor. Nat Immunol (2012) 13:872-9. doi:10.1038/ni.2394

126. Zeng X, Wei YL, Huang J, Newell EW, Yu H, Kidd BA, et al. Gammadelta T cells recognize a microbial encoded $\mathrm{B}$ cell antigen to initiate a rapid antigen-specific interleukin-17 response. Immunity (2012) 37:524-34. doi:10.1016/j.immuni. 2012.06.011

127. Groh V, Steinle A, Bauer S, Spies T. Recognition of stress-induced MHC molecules by intestinal epithelial gammadelta T cells. Science (1998) 279:1737-40. doi:10.1126/science.279.5357.1737

128. Wu J, Groh V, Spies T. T cell antigen receptor engagement and specificity in the recognition of stress-inducible MHC class I-related chains by human epithelial gamma delta T cells. J Immunol (2002) 169:1236-40. doi:10.4049/jimmunol. 169.3.1236

129. Xu B, Pizarro JC, Holmes MA, McBeth C, Groh V, Spies T, et al. Crystal structure of a gammadelta T-cell receptor specific for the human MHC class I homolog MICA. Proc Natl Acad Sci U S A (2011) 108:2414-9. doi:10.1073/pnas.1015433108

130. Strominger JL. An alternative path for antigen presentation: group 1 CD1 proteins. J Immunol (2010) 184:3303-5. doi:10.4049/jimmunol.1090008

131. Spada FM, Koezuka Y, Porcelli SA. CD1d-restricted recognition of synthetic glycolipid antigens by human natural killer T cells. J Exp Med (1998) 188:1529-34. doi:10.1084/jem.188.8.1529

132. Mangan BA, Dunne MR, O'Reilly VP, Dunne PJ, Exley MA, O'Shea D, et al. Cutting edge: CD1d restriction and Th1/Th2/Th17 cytokine secretion by human Vdelta3 T cells. J Immunol (2013) 191:30-4. doi:10.4049/jimmunol. 1300121

133. Bai L, Picard D, Anderson B, Chaudhary V, Luoma A, Jabri B, et al. The majority of CD1d-sulfatide-specific T cells in human blood use a semiinvariant Vdeltal TCR. Eur J Immunol (2012) 42:2505-10. doi:10.1002/eji.201242531

134. Luoma AM, Castro CD, Mayassi T, Bembinster LA, Bai L, Picard D, et al. Crystal structure of Vdeltal T cell receptor in complex with CD1d-sulfatide shows MHC-like recognition of a self-lipid by human gammadelta T cells. Immunity (2013) 39:1032-42. doi:10.1016/j.immuni.2013.11.001

135. Uldrich AP, Le Nours J, Pellicci DG, Gherardin NA, McPherson KG, Lim RT, et al. CD1d-lipid antigen recognition by the gammadelta TCR. Nat Immunol (2013) 14:1137-45. doi:10.1038/ni.2713

136. Agea E, Russano A, Bistoni O, Mannucci R, Nicoletti I, Corazzi L, et al. Human CD1-restricted T cell recognition of lipids from pollens. J Exp Med (2005) 202:295-308. doi:10.1084/jem.20050773

137. Esmon CT. Structure and functions of the endothelial cell protein C receptor. Crit Care Med (2004) 32:S298-301. doi:10.1097/01.CCM.0000126128. 64614.81

138. Corvaisier M, Moreau-Aubry A, Diez E, Bennouna J, Mosnier JF, Scotet E, et al. $\mathrm{V}$ gamma 9V delta $2 \mathrm{~T}$ cell response to colon carcinoma cells. J Immunol (2005) 175:5481-8. doi:10.4049/jimmunol.175.8.5481
139. Orsini DL, Res PC, Van Laar JM, Muller LM, Soprano AE, Kooy YM, et al. A subset of $\mathrm{V}$ delta $1+\mathrm{T}$ cells proliferates in response to Epstein-Barr virus-transformed B cell lines in vitro. Scand J Immunol (1993) 38:335-40. doi:10.1111/j.1365-3083.1993.tb01735.x

140. Das H, Sugita M, Brenner MB. Mechanisms of Vdeltal gammadelta T cell activation by microbial components. J Immunol (2004) 172:6578-86. doi:10.4049/jimmunol.172.11.6578

141. Chodaczek G, Papanna V, Zal MA, Zal T. Body-barrier surveillance by epidermal gammadelta TCRs. Nat Immunol (2012) 13:272-82. doi:10.1038/ ni. 2240

142. Ramsay HM, Fryer AA, Hawley CM, Smith AG, Harden PN. Non-melanoma skin cancer risk in the Queensland renal transplant population. Br J Dermatol (2002) 147:950-6. doi:10.1046/j.1365-2133.2002.04976.x

143. Webster AC, Craig JC, Simpson JM, Jones MP, Chapman JR. Identifying high risk groups and quantifying absolute risk of cancer after kidney transplantation: a cohort study of 15,183 recipients. Am J Transplant (2007) 7:2140-51. doi:10.1111/j.1600-6143.2007.01908.x

144. Vajdic CM, McDonald SP, McCredie MR, van Leeuwen MT, Stewart JH, Law M, et al. Cancer incidence before and after kidney transplantation. JAMA (2006) 296:2823-31. doi:10.1001/jama.296.23.2823

145. Kasiske BL, Snyder JJ, Gilbertson DT, Wang C. Cancer after kidney transplantation in the United States. Am J Transplant (2004) 4:905-13. doi:10.1111/j. 1600-6143.2004.00450.x

146. Shankaran V, Ikeda H, Bruce AT, White JM, Swanson PE, Old LJ, et al. IFNgamma and lymphocytes prevent primary tumour development and shape tumour immunogenicity. Nature (2001) 410:1107-11. doi:10.1038/ 35074122

147. Imai K, Matsuyama S, Miyake S, Suga K, Nakachi K. Natural cytotoxic activity of peripheral-blood lymphocytes and cancer incidence: an 11-year follow-up study of a general population. Lancet (2000) 356:1795-9. doi:10.1016/S01406736(00)03231-1

148. Pages F, Berger A, Camus M, Sanchez-Cabo F, Costes A, Molidor R, et al. Effector memory T cells, early metastasis, and survival in colorectal cancer. $N$ Engl J Med (2005) 353:2654-66. doi:10.1056/NEJMoa051424

149. Yee C, Thompson JA, Byrd D, Riddell SR, Roche P, Celis E, et al. Adoptive T cell therapy using antigen-specific CD8+ T cell clones for the treatment of patients with metastatic melanoma: in vivo persistence, migration, and antitumor effect of transferred T cells. Proc Natl Acad Sci U S A (2002) 99:16168-73. doi:10.1073/pnas.242600099

150. Hunder NN, Wallen H, Cao J, Hendricks DW, Reilly JZ, Rodmyre R, et al. Treatment of metastatic melanoma with autologous CD4+ T cells against NYESO-1. N Engl J Med (2008) 358:2698-703. doi:10.1056/NEJMoa0800251

151. Girardi M, Oppenheim DE, Steele CR, Lewis JM, Glusac E, Filler R, et al. Regulation of cutaneous malignancy by gammadelta T cells. Science (2001) 294:605-9. doi:10.1126/science.1063916

152. Bachelez H, Flageul B, Degos L, Boumsell L, Bensussan A. TCR gamma delta bearing $\mathrm{T}$ lymphocytes infiltrating human primary cutaneous melanomas. J Invest Dermatol (1992) 98:369-74. doi:10.1111/1523-1747.ep12499808

153. Bialasiewicz AA, Ma JX, Richard G. Alpha/beta- and gamma/delta TCR $(+)$ lymphocyte infiltration in necrotising choroidal melanomas. Br J Ophthalmol (1999) 83:1069-73. doi:10.1136/bjo.83.9.1069

154. Nanno M, Seki H, Mathioudakis G, Suzuki R, Itoh K, Ioannides CG, et al. Gamma/delta $T$ cell antigen receptors expressed on tumor-infiltrating lymphocytes from patients with solid tumors. Eur J Immunol (1992) 22:679-87. doi:10.1002/eji.1830220310

155. Choudhary A, Davodeau F, Moreau A, Peyrat MA, Bonneville M, Jotereau F. Selective lysis of autologous tumor cells by recurrent gamma delta tumorinfiltrating lymphocytes from renal carcinoma. J Immunol (1995) 154:3932-40.

156. Hacker G, Kromer S, Falk M, Heeg K, Wagner H, Pfeffer K. V delta 1+ subset of human gamma delta $\mathrm{T}$ cells responds to ligands expressed by EBV-infected Burkitt lymphoma cells and transformed B lymphocytes. J Immunol (1992) 149:3984-9.

157. Catellani S, Poggi A, Bruzzone A, Dadati P, Ravetti JL, Gobbi M, et al. Expansion of Vdelta1 T lymphocytes producing IL-4 in low-grade non-Hodgkin lymphomas expressing UL-16-binding proteins. Blood (2007) 109:2078-85. doi:10.1182/blood-2006-06-028985

158. Ma C, Zhang Q, Ye J, Wang F, Zhang Y, Wevers E, et al. Tumor-infiltrating gammadelta $\mathrm{T}$ lymphocytes predict clinical outcome in human breast cancer. J Immunol (2012) 189:5029-36. doi:10.4049/jimmunol.1201892 
159. Wakita D, Sumida K, Iwakura Y, Nishikawa H, Ohkuri T, Chamoto K, et al. Tumor-infiltrating IL-17-producing gammadelta T cells support the progression of tumor by promoting angiogenesis. Eur J Immunol (2010) 40:1927-37. doi:10.1002/eji.200940157

160. Ma S, Cheng Q, Cai Y, Gong H, Wu Y, Yu X, et al. IL-17A produced by gammadelta $\mathrm{T}$ cells promotes tumor growth in hepatocellular carcinoma. Cancer Res (2014) 74:1969-82. doi:10.1158/0008-5472.CAN-13-2534

161. Rei M, Goncalves-Sousa N, Lanca T, Thompson RG, Mensurado S, Balkwill FR, et al. Murine CD27(-) Vgamma6(+) gammadelta T cells producing IL-17A promote ovarian cancer growth via mobilization of protumor small peritoneal macrophages. Proc Natl Acad Sci U S A (2014) 111:E3562-70. doi:10.1073/pnas.1403424111

162. Fisher JP, Heuijerjans J, Yan M, Gustafsson K, Anderson J. Gammadelta T cells for cancer immunotherapy: a systematic review of clinical trials. Oncoimmunology (2014) 3:e27572. doi:10.4161/onci.27572

163. Albonico HU, Braker HU, Husler J. Febrile infectious childhood diseases in the history of cancer patients and matched controls. Med Hypotheses (1998) 51:315-20. doi:10.1016/S0306-9877(98)90055-X

164. Krone B, Kolmel KF, Grange JM, Mastrangelo G, Henz BM, Botev IN, et al. Impact of vaccinations and infectious diseases on the risk of melanoma evaluation of an EORTC case-control study. Eur J Cancer (2003) 39:2372-8. doi:10.1016/S0959-8049(03)00625-7

165. Devaud C, Bilhere E, Loizon S, Pitard V, Behr C, Moreau JF, et al. Antitumor activity of gammadelta $\mathrm{T}$ cells reactive against cytomegalovirus-infected cells in a mouse xenograft tumor model. Cancer Res (2009) 69:3971-8. doi:10.1158/0008-5472.CAN-08-3037

166. Devaud C, Rousseau B, Netzer S, Pitard V, Paroissin C, Khairallah C, et al. Antimetastatic potential of human Vdelta1(+) gammadelta $\mathrm{T}$ cells in an orthotopic mouse xenograft model of colon carcinoma. Cancer Immunol Immunother (2013) 62:1199-210. doi:10.1007/s00262-013-1402-1

167. Couzi L, Levaillant Y, Jamai A, Pitard V, Lassalle R, Martin K, et al. Cytomegalovirus-induced gammadelta $\mathrm{T}$ cells associate with reduced cancer risk after kidney transplantation. J Am Soc Nephrol (2010) 21:181-8. doi:10.1681/ASN.2008101072

168. Elmaagacli AH, Steckel NK, Koldehoff M, Hegerfeldt Y, Trenschel R, Ditschkowski M, et al. Early human cytomegalovirus replication after transplantation is associated with a decreased relapse risk: evidence for a putative virus-versus-leukemia effect in acute myeloid leukemia patients. Blood (2012) 118:1402-12. doi:10.1182/blood-2010-08-304121

169. Green ML, Leisenring WM, Xie H, Walter RB, Mielcarek M, Sandmaier $\mathrm{BM}$, et al. CMV reactivation after allogeneic HCT and relapse risk: evidence for early protection in acute myeloid leukemia. Blood (2013) 122:1316-24. doi:10.1182/blood-2013-02-487074

170. Godder KT, Henslee-Downey PJ, Mehta J, Park BS, Chiang KY, Abhyankar S, et al. Long term disease-free survival in acute leukemia patients recovering with increased gammadelta $\mathrm{T}$ cells after partially mismatched related donor bone marrow transplantation. Bone Marrow Transplant (2007) 39:751-7. doi:10.1038/sj.bmt.1705650

171. Courivaud C, Bamoulid J, Gaugler B, Roubiou C, Arregui C, Chalopin JM, et al. Cytomegalovirus exposure, immune exhaustion and cancer occurrence in renal transplant recipients. Transpl Int (2012) 25:948-55. doi:10.1111/j.1432-2277. 2012.01521.x

172. Harkins L, Volk AL, Samanta M, Mikolaenko I, Britt WJ, Bland KI, et al. Specific localisation of human cytomegalovirus nucleic acids and proteins in human colorectal cancer. Lancet (2002) 360:1557-63. doi:10.1016/S0140-6736(02) 11524-8

173. Cobbs CS, Harkins L, Samanta M, Gillespie GY, Bharara S, King PH, et al. Human cytomegalovirus infection and expression in human malignant glioma. Cancer Res (2002) 62:3347-50.

174. Soderberg-Naucler C. Does cytomegalovirus play a causative role in the development of various inflammatory diseases and cancer? J Intern Med (2006) 259:219-46. doi:10.1111/j.1365-2796.2006.01618.x

175. Maussang D, Verzijl D, van Walsum M, Leurs R, Holl J, Pleskoff O, et al. Human cytomegalovirus-encoded chemokine receptor US28 promotes tumorigenesis. Proc Natl Acad Sci U S A (2006) 103:13068-73. doi:10.1073/ pnas.0604433103

176. Waldman WJ, Knight DA, Adams PW, Orosz CG, Sedmak DD. In vitro induction of endothelial HLA class II antigen expression by cytomegalovirus-activated CD4+ T cells. Transplantation (1993) 56:1504-12. doi:10.1097/00007890-199312000-00043

177. Waldman WJ, Knight DA. Cytokine-mediated induction of endothelial adhesion molecule and histocompatibility leukocyte antigen expression by cytomegalovirus-activated T cells. Am J Pathol (1996) 148:105-19.

178. Amir AL, D'Orsogna LJ, Roelen DL, van Loenen MM, Hagedoorn RS, de Boer $\mathrm{R}$, et al. Allo-HLA reactivity of virus-specific memory T cells is common. Blood (2010) 115:3146-57. doi:10.1182/blood-2009-07-234906

179. Gamadia LE, Remmerswaal EB, Surachno S, Lardy NM, Wertheim-van Dillen PM, van Lier RA, et al. Cross-reactivity of cytomegalovirus-specific CD8+ T cells to allo-major histocompatibility complex class I molecules. Transplantation (2004) 77:1879-85. doi:10.1097/01.TP.0000131158.81346.64

180. Smith JM, Corey L, Bittner R, Finn LS, Healey PJ, Davis CL, et al. Subclinical viremia increases risk for chronic allograft injury in pediatric renal transplantation. J Am Soc Nephrol (2010) 21:1579-86. doi:10.1681/ASN.2009111188

181. Dzabic M, Rahbar A, Yaiw KC, Naghibi M, Religa P, Fellstrom B, et al. Intragraft cytomegalovirus protein expression is associated with reduced renal allograft survival. Clin Infect Dis (2011) 53:969-76. doi:10.1093/cid/cir619

182. Helantera I, Loginov R, Koskinen P, Tornroth T, Gronhagen-Riska C, Lautenschlager I. Persistent cytomegalovirus infection is associated with increased expression of TGF-beta1, PDGF-AA and ICAM-1 and arterial intimal thickening in kidney allografts. Nephrol Dial Transplant (2005) 20:790-6. doi:10. 1093/ndt/gfh714

183. Colvin RB. Antibody-mediated renal allograft rejection: diagnosis and pathogenesis. J Am Soc Nephrol (2007) 18:1046-56. doi:10.1681/ASN.2007010073

184. Einecke G, Sis B, Reeve J, Mengel M, Campbell PM, Hidalgo LG, et al. Antibodymediated microcirculation injury is the major cause of late kidney transplant failure. Am J Transplant (2009) 9:2520-31. doi:10.1111/j.1600-6143. 2009.02799.x

185. Loupy A, Hill GS, Jordan SC. The impact of donor-specific anti-HLA antibodies on late kidney allograft failure. Nat Rev Nephrol (2012) 8:348-57. doi:10.1038/nrneph.2012.81

186. Bentall A, Cornell LD, Gloor JM, Park WD, Gandhi MJ, Winters JL, et al. Fiveyear outcomes in living donor kidney transplants with a positive crossmatch. Am J Transplant (2013) 13:76-85. doi:10.1111/j.1600-6143.2012.04291.x

187. Stegall MD, Chedid MF, Cornell LD. The role of complement in antibodymediated rejection in kidney transplantation. Nat Rev Nephrol (2012) 8:670-8. doi:10.1038/nrneph.2012.212

188. Loupy A, Suberbielle-Boissel C, Hill GS, Lefaucheur C, Anglicheau D, Zuber J, et al. Outcome of subclinical antibody-mediated rejection in kidney transplant recipients with preformed donor-specific antibodies. Am J Transplant (2009) 9:2561-70. doi:10.1111/j.1600-6143.2009.02813.x

189. Sis B, Einecke G, Chang J, Hidalgo LG, Mengel M, Kaplan B, et al. Cluster analysis of lesions in nonselected kidney transplant biopsies: microcirculation changes, tubulointerstitial inflammation and scarring. Am J Transplant (2010) 10:421-30. doi:10.1111/j.1600-6143.2009.02938.x

190. Sis B, Jhangri GS, Riopel J, Chang J, de Freitas DG, Hidalgo L, et al. A new diagnostic algorithm for antibody-mediated microcirculation inflammation in kidney transplants. Am J Transplant (2012) 12:1168-79. doi:10.1111/j.16006143.2011.03931.x

191. Sis B, Mengel M, Haas M, Colvin RB, Halloran PF, Racusen LC, et al. Banff ' 09 meeting report: antibody mediated graft deterioration and implementation of Banff working groups. Am J Transplant (2010) 10:464-71. doi:10.1111/j.1600-6143.2009.02987.x

192. Sellares J, de Freitas DG, Mengel M, Reeve J, Einecke G, Sis B, et al. Understanding the causes of kidney transplant failure: the dominant role of antibodymediated rejection and nonadherence. Am J Transplant (2011) 12:388-99. doi:10.1111/j.1600-6143.2011.03840.x

193. Zhang X, Reed EF. Effect of antibodies on endothelium. Am J Transplant (2009) 9:2459-65. doi:10.1111/j.1600-6143.2009.02819.x

194. Hidalgo LG, Sellares J, Sis B, Mengel M, Chang J, Halloran PF. Interpreting NK cell transcripts versus T cell transcripts in renal transplant biopsies. Am J Transplant (2012) 12:1180-91. doi:10.1111/j.1600-6143.2011.03970.x

195. Hidalgo LG, Sis B, Sellares J, Campbell PM, Mengel M, Einecke G, et al. NK cell transcripts and NK cells in kidney biopsies from patients with donor-specific antibodies: evidence for NK cell involvement in antibodymediated rejection. Am J Transplant (2010) 10:1812-22. doi:10.1111/j.16006143.2010.03201.x 
196. Feucht HE, Schneeberger H, Hillebrand G, Burkhardt K, Weiss M, Riethmuller $\mathrm{G}$, et al. Capillary deposition of C4d complement fragment and early renal graft loss. Kidney Int (1993) 43:1333-8. doi:10.1038/ki.1993.187

197. Mengel M, Sis B, Haas M, Colvin RB, Halloran PF, Racusen LC, et al. Banff 2011 Meeting report: new concepts in antibody-mediated rejection. Am J Transplant (2012) 12:563-70. doi:10.1111/j.1600-6143.2011.03926.x

198. Loupy A, Hill GS, Suberbielle C, Charron D, Anglicheau D, Zuber J, et al. Significance of C4d Banff scores in early protocol biopsies of kidney transplant recipients with preformed donor-specific antibodies (DSA). Am J Transplant (2011) 11:56-65. doi:10.1111/j.1600-6143.2010.03364.x

199. Einecke G, Mengel M, Hidalgo L, Allanach K, Famulski KS, Halloran PF. The early course of kidney allograft rejection: defining the time when rejection begins. Am J Transplant (2009) 9:483-93. doi:10.1111/j.1600-6143.2008. 02546.x

200. Haas M, Sis B, Racusen LC, Solez K, Glotz D, Colvin RB, et al. Banff 2013 meeting report: inclusion of c4d-negative antibody-mediated rejection and antibody-associated arterial lesions. Am J Transplant (2014) 14:272-83. doi:10.1111/ajt.12590

201. Sellares J, Reeve J, Loupy A, Mengel M, Sis B, Skene A, et al. Molecular diagnosis of antibody-mediated rejection in human kidney transplants. Am J Transplant (2013) 13:971-83. doi:10.1111/ajt.12150

202. Bachelet T, Couzi L, Pitard V, Sicard X, Rigothier C, Lepreux S, et al. Cytomegalovirus-responsive gammadelta $\mathrm{T}$ cells: novel effector cells in antibody-mediated kidney allograft microcirculation lesions. J Am Soc Nephrol (2014) 25:2471-82. doi:10.1681/ASN.2013101052

203. Papadimitriou JC, Drachenberg CB, Munivenkatappa R, Ramos E, Nogueira J, Sailey C, et al. Glomerular inflammation in renal allografts biopsies after the first year: cell types and relationship with antibody-mediated rejection and graft outcome. Transplantation (2010) 90:1478-85. doi:10.1097/TP. 0b013e3181ff87f5

204. Tong CY, Bakran A, Peiris JS, Muir P, Herrington CS. The association of viral infection and chronic allograft nephropathy with graft dysfunction after renal transplantation. Transplantation (2002) 74:576-8. doi:10.1097/ 00007890-200208270-00026

205. Li Y, Koshiba T, Yoshizawa A, Yonekawa Y, Masuda K, Ito A, et al. Analyses of peripheral blood mononuclear cells in operational tolerance after pediatric living donor liver transplantation. Am J Transplant (2004) 4:2118-25. doi:10.1111/j.1600-6143.2004.00611.x

206. Koshiba T, Li Y, Takemura M, Wu Y, Sakaguchi S, Minato N, et al. Clinical, immunological, and pathological aspects of operational tolerance after pediatric living-donor liver transplantation. Transpl Immunol (2007) 17:94-7. doi:10.1016/j.trim.2006.10.004
207. Martinez-Llordella M, Puig-Pey I, Orlando G, Ramoni M, Tisone G, Rimola A, et al. Multiparameter immune profiling of operational tolerance in liver transplantation. Am J Transplant (2007) 7:309-19. doi:10.1111/j.1600-6143.2006. 01621.x

208. Martinez-Llordella M, Lozano JJ, Puig-Pey I, Orlando G, Tisone G, Lerut J, et al. Using transcriptional profiling to develop a diagnostic test of operational tolerance in liver transplant recipients. J Clin Invest (2008) 118:2845-57. doi:10.1172/JCI35342

209. Zhao X, Li Y, Ohe H, Nafady-Hego H, Uemoto S, Bishop GA, et al. Intragraft Vdeltal gammadelta $\mathrm{T}$ cells with a unique T-cell receptor are closely associated with pediatric semiallogeneic liver transplant tolerance. Transplantation (2013) 95:192-202. doi:10.1097/TP.0b013e3182782f9f

210. Silva-Santos B, Schamel WW, Fisch P, Eberl M. Gammadelta T-cell conference 2012: close encounters for the fifth time. Eur J Immunol (2012) 42:3101-5. doi:10.1002/eji.201270101

211. Deniger DC, Maiti S, Mi T, Switzer K, Ramachandran V, Hurton LV, et al. Activating and propagating polyclonal gamma delta $\mathrm{T}$ cells with broad specificity for malignancies. Clin Cancer Res (2014) 20:5708-19. doi:10.1158/1078-0432. CCR-13-3451

212. Fisher J, Yan M, Heuijerjans J, Carter L, Abolhassani A, Frosch J, et al. Neuroblastoma killing properties of V-delta 2 and V-delta2 negative gamma delta $\mathrm{T}$ cells following expansion by artificial antigen presenting cells. Clin Cancer Res (2014) 20:5720-32. doi:10.1158/1078-0432.CCR-13-3464

Conflict of Interest Statement: The authors declare that the research was conducted in the absence of any commercial or financial relationships that could be construed as a potential conflict of interest.

Received: 12 November 2014; accepted: 04 January 2015; published online: 21 January 2015.

Citation: Couzi L, Pitard V, Moreau J-F, Merville P and Déchanet-Merville J (2015) Direct and indirect effects of cytomegalovirus-induced $\gamma \delta$ T cells after kidney transplantation. Front. Immunol. 6:3. doi: 10.3389/fimmu.2015.00003

This article was submitted to T Cell Biology, a section of the journal Frontiers in Immunology.

Copyright (c) 2015 Couzi, Pitard, Moreau, Merville and Déchanet-Merville. This is an open-access article distributed under the terms of the Creative Commons Attribution License (CC BY). The use, distribution or reproduction in other forums is permitted, provided the original author(s) or licensor are credited and that the original publication in this journal is cited, in accordance with accepted academic practice. No use, distribution or reproduction is permitted which does not comply with these terms. 